\title{
Detection and Characterization of Human High Molecular Weight B Cell Growth Factor Receptors on Leukemic B Cells in Chronic Lymphocytic Leukemia
}

Fatih M. Uckun, ${ }^{\star}$ Anthony S. Fauci, ${ }^{\ddagger}$ Mridula Chandan-Langlie, ${ }^{\star}$ Dorothea E. Myers, ${ }^{\star}$ and Julian L. Ambrus ${ }^{\ddagger}$

*Tumor Immunology Laboratory/Departments of Therapeutic Radiology-Radiation Oncology, Pediatrics, and Bone Marrow

Transplantation Program, University of Minnesota, Minneapolis, Minnesota 55455; ${ }^{\ddagger}$ Laboratory of Immunoregulation,

National Institute of Allergy and Infectious Diseases, Bethesda, Maryland 20205

\section{Abstract}

Human high molecular weight-B cell growth factor (HMWBCGF) (60 kD) stimulates activated normal $B$ cells, $B$ cell precursor acute lymphoblastic leukemia (BCP-ALL) cells, hairy cell leukemia (HCL) cells, prolymphocytic leukemia (PLL) cells, and chronic lymphocytic leukemia (CLL) cells. The expression of human high molecular weight $B$ cell growth factor (HMW-BCGF) receptors (R) on clonal populations of leukemic B cells in CLL was studied by ligand binding assays using ${ }^{125}$ I-labeled HMW-BCGF as well as by immunofluorescence/flow cytometry and Scatchard analyses using an antiHMW-BCGF $R$ monoclonal antibody (MAb), designated BA-5. There was a high correlation between HMW-BCGF $R$ expression and responsiveness to HMW-BCGF. 60\% of CLL cases constitutively expressed HMW-BCGF $R$ and showed a marked proliferative response to $H M W-B C G F$ in $\left[{ }^{3} H\right] T d R$ incorporation assays as well as colony assays. Similarly, HCL cells, PLL cells, and activated normal B cells expressed functional HMW-BCGF R, as determined by ligand binding assays using ${ }^{125} \mathrm{I}-\mathrm{HMW}-\mathrm{BCGF},\left[{ }^{3} \mathrm{H}\right] \mathrm{TdR}$ incorporation assays, and reactivity with BA-5 MAb. Scatchard analyses indicated the existence of $\sim 3,000 \mathrm{HMW}$-BCGF R/cell on HMW-BCGF responsive CLL cells with an apparent $K_{\mathrm{a}}$ value of $4.6 \times 10^{7}$ $M^{-1}$. The concentrations of HMW-BCGF required for maximum stimulation of CLL cells were two to three orders of magnitude lower than those needed for half maximal receptor occupancy, indicating that only a small fraction of HMWBCGF $R$ need to be occupied to stimulate leukemic CLL B cells. Crosslinking of surface bound ${ }^{125}$ I-HMW-BCGF (60 $k D)$ with the bivalent crosslinker DTSSP to its binding site on fresh CLL cells identified a 150-kD HMW-BCGF/HMWBCGF $R$ complex, suggesting an apparent molecular weight of $90 \mathrm{kD}$ for the receptor protein. The growth stimulatory effects of HMW-BCGF on clonogenic CLL cells did not depend on accessory cells or costimulant factors. The anti-HMW-BCGF $R$ monoclonal antibody BA-5 disrupted HMW-BCGF/ HMW-BCGF $R$ interactions at the level of clonogenic CLL cells and inhibited HMW-BCGF-stimulated CLL colony for-

Address reprint requests to Dr. Fatih M. Uckun, Tumor Immunology Laboratory, Box 356, University of Minnesota Hospital and Clinic, 420 Delaware Street, S. E., Minneapolis, MN 55455.

Received for publication 29 July 1988 and in revised form 16 June 1989.

J. Clin. Invest.

(c) The American Society for Clinical Investigation, Inc.

$0021-9738 / 89 / 11 / 1595 / 14 \$ 2.00$

Volume 84, November 1989, 1595-1608 mation in vitro. To our knowledge, this study represents the first detailed analysis of expression, function, and structure of HMW-BCGF R on B lineage CLL cells.

\section{Introduction}

Human B lymphocyte development is a multistep maturation process that involves activation, proliferation, and differentiation accompanied by a coordinated acquisition and loss of $B$ lineage differentiation/activation antigens and surface growth factor $(G F)^{1} R$. Uncoupling of proliferation and differentiation may occur at multiple stages of $B$ cell ontogeny and is thought to be the underlying mechanism for the stabilization and expansion of transitory cellular phenotypes leading to $B$ lineage lymphoid malignancies (1). Several candidate hematopoietic GF have been described that may play a key role in proliferation and differentiation of human B lineage cells (2-11). Current areas of intense investigation include analysis of the structural and functional features of these biomodulatory molecules, identification and characterization of their $\mathbf{R}$, and elucidation of their roles in human $B$ lymphocyte development as well as in leukemogenesis and disease progression of $B$ lineage lymphoid malignancies (1-34). One of these factors is a 60-kD high molecular weight-B cell growth factor (HMWBCGF), which is produced by normal $\mathrm{T}$ cells, $\mathrm{T}$ cell clones, and $T$ lineage as well as $B$ lineage lymphoma cell lines and provides a potent progression/proliferation signal for activated B cells $(7,8)$. The availability of highly purified HMW-BCGF (8) and a monoclonal antibody (BA-5) reactive with the receptor for HMW-BCGF (17) permit detailed analyses of HMWBCGF R expression, structure, and function. Resting normal tonsillary or peripheral blood B lymphocytes express only 50-350 HMW-BCGF R/cell and do not show any significant proliferative response to HMW-BCGF (17). By comparison, activated normal tonsillary or peripheral blood B-lymphocytes express 1-5 $\times 10^{4} \mathrm{HMW}$-BCGF R/cell and show a marked proliferative response to HMW-BCGF (17). ${ }^{125} \mathrm{I}-\mathrm{HMW}-\mathrm{BCGF}$ crosslinked to its binding site on Sac-activated B-lymphocytes produces a $150-\mathrm{kD}$ R-protein complex recognized by both BA-5 MAb reactive with the $90-\mathrm{kD}$ ligand binding site of the receptor as well as by $\mathrm{BCGF} / 1 / \mathrm{C} 2 \mathrm{MAb}$ specifically reactive with HMW-BCGF (17).

Our recent studies demonstrated that leukemic BCPs from BCP-ALL patients, but not normal fetal liver or fetal bone marrow BCPs, constitutively express functional HMW-BCGF $\mathbf{R}$ and proliferate in response to HMW-BCGF in the absence

1. Abbreviations used in this paper: ALL, acute lymphocytic leukemia; CLL, chronic lymphocytic leukemia; HMW-BCGF R, B cell growth factor receptors. 
of comitogens or accessory cell populations (10-12), providing suggestive evidence that HMW-BCGF may play an important regulatory role in clonal expansion of neoplastic $B$ cell precursor populations in "immature" B cell malignancies (12). The bioactivities and growth regulatory role of $60 \mathrm{kD} H \mathrm{HW}$ BCGF in "mature" B cell malignancies, such as CLL, has not as yet been analyzed.

The purpose of the present study was the detection and characterization of HMW-BCGF $R$ in CLL. We used ${ }^{125} \mathrm{I}$ labeled purified HMW-BCGF and BA-5 MAb reactive with the ligand binding site of HMW-BCGF $R$ to analyze the constitutive expression of HMW-BCGF R on freshly isolated leukemic CLL B cells. Equilibrium binding assays were performed using ${ }^{125}$ I labeled BA-5 MAb to determine the number and affinity of HMW-BCGF $R$ on CLL cells. The structural nature of HMW-BCGF $R$ was analyzed in affinity crosslinking experiments. The function of the identified HMW-BCGF $R$ and the growth stimulatory effects of HMW-BCGF on CLL B cells were studied in $\left[{ }^{3} \mathrm{H}\right] \mathrm{TdR}$ incorporation and colony assays. We present direct evidence for the constitutive expression of a single class of $\sim 3,000$ functional $90 \mathrm{kD}$ HMW-BCGF $R$ on HMW-BCGF responsive leukemic CLL B cells, which mediate stimulatory signals for CLL cells in the absence of comitogens or accessory cell populations. Furthermore, we show that the anti-HMW-BCGF $R$ MAb BA-5 reacts with a significant fraction of CLL cells in HMW-BCGF responsive cases and specifically inhibits HMW-BCGF induced proliferation of CLL cells. Also provided is initial evidence for the constitutive expression of functional HMW-BCGF R on HCL and PLL cells.

\section{Methods}

Reagents. MAbs 35.1 (anti-CD2), OKT3 (anti-CD3), T101 (antiCD5), BA-3/24.1 (anti-CDi0), B43 (anti-CD19), B1 (anti-CD20), G28-7/Leu14 (anti-CD22), BA-1 (anti-CD24), G28.8 (anti-Bgp95), G28-5 (anti-CD40), BA-5 (anti-HMW-BCGF R), and LeuM-5 (antiCD11c) were used to study the surface antigen profiles of leukemic cells by indirect immunofluorescence, as previously described (13-16). In some experiments, cells were two-color stained for HMW-BCGF R and CD19 using BA-5-FITC and B43-PE, as previously described (10, 13). The presence of surface and cytoplasmic immunoglobulin (Ig) was studied by direct immunofluorescence using rabbit antisera specific to human IgM, IgD, IgA, IgG heavy chains, and kappa and lambda light chains. Biochemically purified HMW-BCGF and LMW-BCGF and ${ }^{125} \mathrm{I}$-HMW-BCGF $\left(1 \times 10^{17} \mathrm{cpm} / \mathrm{mol}\right)$ were prepared as previously reported $(6,8,12)$. Purification and ${ }^{125} \mathrm{I}$ labeling of $\mathrm{BA}-5 \mathrm{MAb}$ has been previously described in detail (17). The specific activity of ${ }^{125}$ I-BA-5 was $1.5 \times 10^{17} \mathrm{cpm} / \mathrm{mol}\left(=1 \times 10^{6} \mathrm{cpm} / \mu \mathrm{g}\right)$. The purity of ${ }^{125} \mathrm{I}$-HMWBCGF and ${ }^{125}$ I-BA-5 was confirmed by an analytical SDS-PAGE and autoradiography which revealed single bands (Fig. 1): In brief, aliquots of ${ }^{125}$ I labeled HMW-BCGF $(\sim 200,000 \mathrm{cpm})$ and BA-5 $(\sim 100,000$ cpm) were boiled in Tris buffer containing SDS, glycerol, and bromophenol blue tracking dye, and run on a 7.5\% mini-gel (Mini-Protean II; Bio-Rad Laboratories Richmond, CA), according to the method of Laemmli and as previously reported $(33,34)$. The gel was dried and exposed at $-70^{\circ} \mathrm{C}$ for $30 \mathrm{~h}$ using Kodak XAR-5 film and Dupont Quanta II Cronex enhancer screens, as previously described $(33,34)$. The positions of the prestained molecular weight standards, including $\beta$-galactosidase (116 kD), phosphorylase B $(95.5 \mathrm{kD})$, and glutamate dehydrogenase $(55 \mathrm{kD})$ are indicated on the left (Fig. 1). The autoradiograms were scanned using DU-62 Spectrophotometer equipped with a gel scanning attachment (Beckman Instruments, Inc., Fullerton, CA). Quantitation of the radioactivity in the HMW-BCGF and BA-5 bands was carried out by densitometric analysis using the gel scan

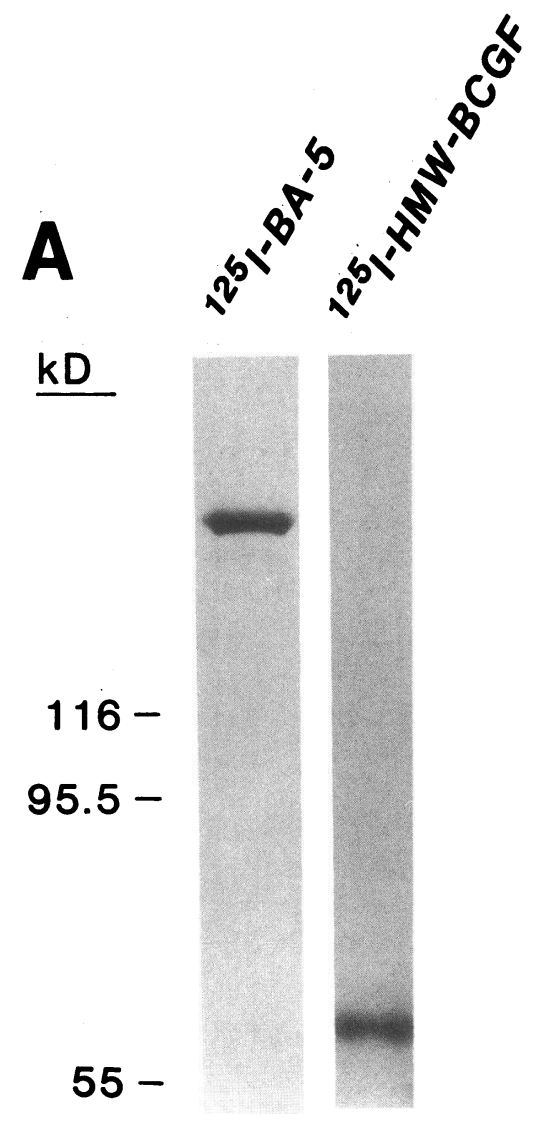

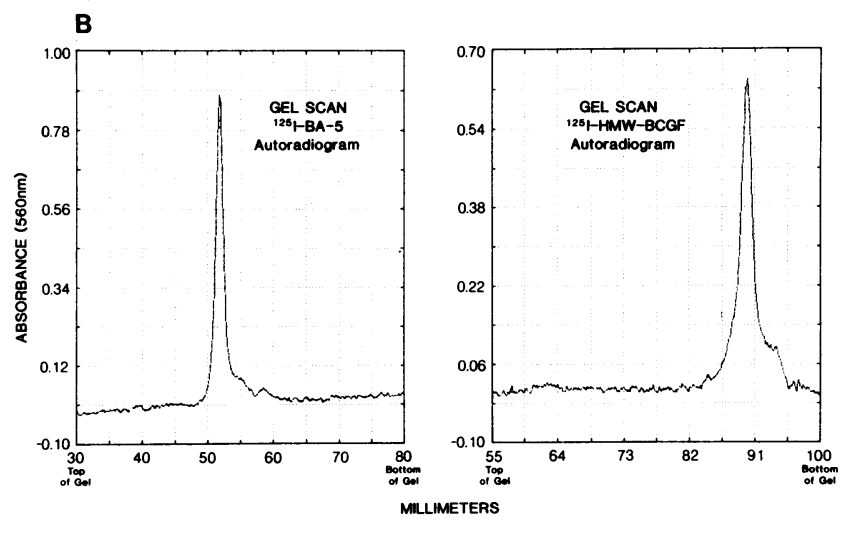

Figure 1. Autoradiograms of ${ }^{125} \mathrm{I}-\mathrm{HMW}$ BCGF and ${ }^{125} \mathrm{I}-\mathrm{BA}-5$. Autoradiography and gel scanning were performed as described in detail in Methods. HMW-BCGF and BA-5 bands represented $>99 \%$ of the radioactivity in the respective lanes. 
soft-pac module software (Beckman). As shown in Fig. 1, ${ }^{125}$ I-HMWBCGF and ${ }^{125} \mathrm{I}-\mathrm{BA}-5$ represented $>99 \%$ of the radioactivity in the respective lanes.

Patient material. 18 patients with CLL were studied. Diagnosis was based upon standard clinical criteria and the morphological, cytochemical, and immunological marker profiles of bone marrow and/or peripheral blood lymphocytes. Peripheral blood and bone marrow samples from these patients were obtained and used by following the guidelines of the University of Minnesota Committee on the Use of Human Subjects in research for secondary use of pathological or surgical tissue. Peripheral blood or bone marrow mononuclear cells were isolated by density-gradient separation on Ficoll-Hypaque gradients. The cells had a $\left[\mathrm{CD} 2^{-} \mathrm{CD} 3^{-} \mathrm{CD} 5^{+} \mathrm{CD} 10^{-} \mathrm{CD} 19^{+} \mathrm{CD} 20^{+} \mathrm{CD} 24^{+}\right.$$\mathrm{CD} 1 \mathrm{cc}^{-} \mathrm{sIg}^{+}$] composite immunophenotype, which is consistent with CLL. The surface/cytoplasmic Ig profile confirmed the clonality of the analyzed CLL populations. Of these 18 CLL cases, 10 (CLL 1-CLL 10) were analyzed in detail for the function and/or structure of the detected HMW-BCGF R. Patient data on these 10 cases, including the immunophenotypic features of leukemic cells, are detailed in Table I. The remaining eight cases were analyzed for HMW-BCGF R expression only by immunofluorescence using BA-5 MAb. Also analyzed for HMW-BCGF R expression were leukemic cells from four $\mathrm{HCl}$ patients $\left[\mathrm{CD} 2^{-} \mathrm{CD}^{-} \mathrm{CD}^{+} \mathrm{CD} 10^{-} \mathrm{CD} 19^{+} \mathrm{CD} 22^{+} \mathrm{CD} 11 \mathrm{c}^{+}\right], 2$ PLL patients $\left[\mathrm{CD} 2^{-} \mathrm{CD}^{-} \mathrm{CD}^{+} \mathrm{CD} 10^{-} \mathrm{CD} 19^{+} \mathrm{CD} 20^{+} \mathrm{CD} 22^{+} \mathrm{CD} 11 \mathrm{c}^{-} \mathrm{slg}^{+}\right]$, and 6 BCP ALL patients $\left[\mathrm{CD} 2^{-} \mathrm{CD} 5^{-} \mathrm{CD} 7^{-} \mathrm{CD} 10^{+} \mathrm{CD} 19^{+} \mathrm{sIg}^{-}\right]$using ligand binding assays (HCLs) and/or $\left[{ }^{3} \mathrm{H}\right] \mathrm{TdR}$ incorporation assays (HCLs, PLLs, and BCP ALLs). Controls included activated or resting purified human $B$ cells from tonsils and peripheral blood and purified human peripheral blood T-cells. The purification of human B cells and T cells was performed as previously detailed $(7,8)$.

$H M W-B C G F R$ expression and function studies using ligand binding assays/Scatchard analyses, $\left[{ }^{3} H\right] T d R$ incorporation assays, and affinity crosslinking of ${ }^{125} I-H M W-B C G F$. CLL, HCL, PLL, BCP ALL, and normal $B$ cells were initially screened for functional HMW-BCGF $R$ expression using $\left[{ }^{3} \mathrm{H}\right] \mathrm{TdR}$ incorporation assays, as previously described $(7,8,12,17)$. The specific binding of ${ }^{125} \mathrm{I}$-HMW-BCGF (1 $\times 10^{17} \mathrm{cpm} / \mathrm{mol}$ ) to plasma membrane receptors on fresh CLL cells was evaluated in standard ligand binding assays in the presence and absence of 50-fold excess cold HMW-BCGF, as previously described in detail $(12,17)$. Equilibrium binding assays and Scatchard analyses of HMW-BCGF R expression on CLL cells were performed using ${ }^{125} \mathrm{I}$ labeled BA-5 MAb as follows: Cells were washed three times in cold alpha-MEM supplemented with $10 \%$ calf bovine serum, $10 \mathrm{mM}$ Hepes buffer, $1 \%$ penicillin/streptomycin, and $0.1 \%$ sodium azide (binding medium, $\mathrm{pH}$ 7.4). After the final wash, the cells were resuspended in freshly prepared cold binding medium, and maintained at $4^{\circ} \mathrm{C}$ for 60 min before use to halt the internalization of cell surface receptors for HMW-BCGF. All subsequent steps were performed at $4^{\circ} \mathrm{C}$. 5 $\times 10^{-10}-1 \times 10^{-7} \mathrm{M}^{125} \mathrm{I}-\mathrm{BA}-5\left(1.5 \times 10^{17} \mathrm{cpm} / \mathrm{mol}\right)$ with or without 100 -fold molar excess of unlabeled BA-5 MAb was added in $100 \mu \mathrm{L}$ binding medium to $10 \times 10^{6} \mathrm{CLL}$ cells in $150-\mu \mathrm{l}$ duplicate samples so that the final assay volume in each replicate sample was $250 \mu \mathrm{l}$. The samples were gently agitated every $30 \mathrm{~min}$ for $4 \mathrm{~h}$ to prevent the cells from settling and left overnight at $4^{\circ} \mathrm{C}$. At the end of the 24-h incubation period, the cell preparations were diluted 1:1 with calf bovine serum and centrifuged at $4^{\circ} \mathrm{C}$ through a $2-\mathrm{ml}$ calf bovine serum cushion to separate bound and free ${ }^{125} \mathrm{I}-\mathrm{BA}-5$, and the radioactivity associated with the cell pellet (cpm) was determined for a $2-\min$ period by liquid scintillation counting. The radioactivity bound in the presence of excess cold BA-5 was subtracted from the total binding to yield the specific binding. Scatchard plot analysis of the equilibrium binding data was performed was described previously for characterization of IL-1, IL-3, and CD19 receptors on leukemic BCPs, and HMW-BCGF $R$ on activated normal $B$ cells $(13,33,34)$. Affinity cross-linking was performed as described by Lee and Conrad (18) for cross-linking IgE to its Fc receptor on B lymphocytes. HMW-BCGF for these studies was purified to homogeneity by a three-step procedure which consisted of (1) negative immunoabsorption of PHA stimulated Namalwa super-

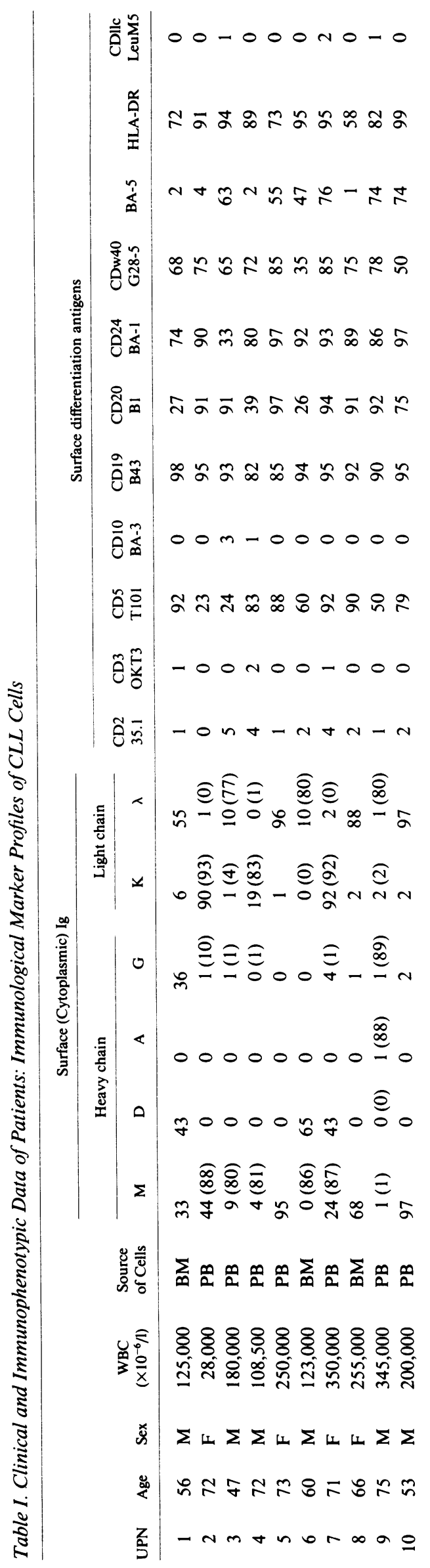


natant with a Sepharose containing polyclonal sera to fetal calf serum proteins, (2) immunoabsorption of the unbound material with a sepharose containing a MAb to HMW-BCGF (BCGF/1/C2) and elution. with $1.5 \%$ acetic acid after washing away unbound material with PBS, and (3) final sieving using $\operatorname{HPLC}(8,12,17) .10 \times 10^{6} \mathrm{CLL}$ cells or SAC activated B cells were incubated with ${ }^{125}$ I-labeled $(50,000 \mathrm{cpm})$ or unlabeled purified HMW-BCGF in $300 \mu$ l RPMI 1640 supplemented with $1 \% \mathrm{BSA}, 0.1 \%$ sodium azide, and $20 \mathrm{mM}$ Hepes for $2 \mathrm{~h}$ at $4^{\circ} \mathrm{C}$. Subsequently, cells were washed twice with PBS and then resuspended in $360 \mu \mathrm{l}$ PBS. $40 \mu \mathrm{l}$ of a freshly prepared $30 \mathrm{mM}$ solution of the bivalent lysine-directed crosslinking agent DTSSP (3,3'-dithiobis-sulfosuccinimidylpropionate) in $50 \mathrm{mM}$ sodium phosphate (pH 7.4) was added and the mixture incubated $30 \mathrm{~min}$ at $4^{\circ} \mathrm{C}$. Cells were then washed twice in PBS and resuspended in $500 \mu \mathrm{l}$ of an aqueous solution containing the protease inhibitors NPGB ( $p$-nitrophenyl $p^{\prime}$-guanidinobenzoate, $25 \mu \mathrm{M})$ and PMSF $(0.1 \mathrm{mM})$. The cells were disrupted on ice by sonication for $1 \mathrm{~min}$ at a level of 1.5-2.0 using a Branson Sonifier Cell Disrupter 200. After centrifugation for $15 \mathrm{~min}$ at $9,000 \mathrm{~g}$ at $4^{\circ} \mathrm{C}$ in an Eppendorf model 5412 centrifuge, the supernatant was evaluated by SDS-PAGE and autoradiography, as previously described (17).

Fluorescence activated cell sorting. Five parameter FACS 440 was used to isolate virtually pure populations of BA-5/HMW-BCGF $\mathbf{R}^{+}$ CLL cells from two CLL patients, as previously described in detail for isolation of B cell precursor populations $(10,12,13)$. BA- $5^{+}$FACS sorted fractions were $>99 \%$ pure as determined by reanalysis on FACS 440. The proliferative responses of these FACS sorted CLL cell populations to HMW-BCGF were determined in a colony assay system, as described hereinafter.

CLL colony assay system. CLL cells were assayed for colony formation in the presence of HMW-BCGF or LMW-BCGF using a colony assay system previously described for cloning leukemic BCPs $(10-15,33,34)$. Cells were suspended in alpha-MEM supplemented with $0.9 \%$ methylcellulose, $30 \%$ calf bovine serum, indicated concentrations of HMW-BCGF or LMW-BCGF, or no added exogenous growth factor. In some experiments, anti-Tac (anti-IL-2 R) or BA-5 (anti-HMW-BCGF R) MAbs $(25 \mu \mathrm{g} / \mathrm{ml})$ were also added to the cultures. Duplicate $1 \mathrm{ml}$ samples containing $3 \times 10^{5} \mathrm{CLL}$ cells were cultured in $35 \mathrm{~mm}$ Petri dishes for $7 \mathrm{~d}$ at $37^{\circ} \mathrm{C}$ in a humidified $5 \%$ atmosphere. On day 7, CLL colonies containing $>20$ cells were counted on a grid using an inverted phase microscope with high optical resolution. Subsequently, immunological analyses of colony cells were performed as described (10-15).

\section{Results}

Stimulatory effects of $H M W-B C G F$ on leukemic $C L L, H C L$, $P L L, B C P$ ALL cells, and normal B cells. Our first goal was to study the effects of HMW-BCGF on DNA synthesis by leukemic CLL B cells using $\left[{ }^{3} \mathrm{H}\right] \mathrm{TdR}$ incorporation assays. As shown in Table II, leukemic B cells from three (CLLs 7, 9, 10) of five CLL patients responded to HMW-BCGF with moderately increased $\left[{ }^{3} \mathrm{H}\right] \mathrm{TdR}$ incorporation in the absence of comitogens or activating agents. The maximum stimulation indices in these cases ranged from 1.4 to 3.1 (mean \pm SE $=2.2 \pm 0.5$ ). Besides CLL cells, leukemic cells from three of four HCL, two of two PLL, and three of six BCP ALL patients also showed a proliferative response to HMW-BCGF with maximum stimulation indices ranging from 2.6 to 21.1 for HCL cells (mean \pm SE $=9.0 \pm 6.1$ ), from 1.5 to 2.0 for PLL cells (mean $=1.8)$, and from 4.4 to $23.6($ mean $\pm \mathrm{SE}=12.1 \pm 5.9)$ for leukemic BCPs (Table II). By comparison, Sac-activated nonleukemic tonsillary B cells from seven of seven tonsillectomy specimens and anti- $\mu$ stimulated nonleukemic tonsillary B cells from two of two tonsillectomy specimens elicited a proliferative response to HMW-BCGF with maximum stimulation
Table II. Stimulatory Effects of HMW-BCGF on Leukemic Cells from CLL, HCL, PLL, and BCP ALL Patients and Normal Tonsillary $B$ Cells

\begin{tabular}{|c|c|c|c|c|c|c|}
\hline \multirow[b]{3}{*}{ Cells } & \multicolumn{5}{|c|}{$\left[{ }^{3} \mathrm{H}\right] \mathrm{TdR}$ Incorporation (mean cpm/ $2 \times 10^{5}$ cells) } & \multirow{3}{*}{$\begin{array}{c}\text { Maximum } \\
\text { stimulation } \\
\text { index }\end{array}$} \\
\hline & \multirow{2}{*}{$\begin{array}{l}\text { No } \\
\text { BCGF }\end{array}$} & \multicolumn{4}{|c|}{ HMW-BCGF (ng/ml) } & \\
\hline & & 0.4 & 1.0 & 2.0 & 4.0 & \\
\hline CLL 2 & 196 & ND & ND & ND & 179 & 0.9 \\
\hline CLL 4 & 171 & ND & 132 & 175 & 142 & 1.0 \\
\hline CLL 7 & 35,679 & ND & 38,905 & 36,579 & 49,494 & 1.4 \\
\hline CLL 9 & 564 & ND & ND & ND & 1,119 & 2.0 \\
\hline CLL 10 & 1,789 & ND & 1,898 & 3,241 & 5,451 & 3.1 \\
\hline HCL 1 & 103 & 189 & 151 & 199 & 327 & 3.2 \\
\hline HCL 2 & 487 & 299 & 346 & 349 & 576 & 1.2 \\
\hline HCL 3 & 285 & ND & ND & ND & 6,016 & 21.1 \\
\hline HCL 4 & 2,227 & 1,918 & 2,099 & 3,232 & 5,715 & 2.6 \\
\hline PLL 1 & 9,151 & ND & ND & ND & 17,845 & 2.0 \\
\hline PLL 2 & 501 & ND & 758 & 747 & 771 & 1.5 \\
\hline BCP ALL 1 & 768 & ND & ND & ND & 3,358 & 4.4 \\
\hline BCP ALL 2 & 1,107 & ND & ND & ND & 9,158 & 8.3 \\
\hline BCP ALL 3 & 1,347 & ND & ND & ND & 1,189 & 0.9 \\
\hline BCP ALL 4 & 789 & ND & ND & ND & 859 & 1.1 \\
\hline BCP ALL 5 & 347 & ND & ND & ND & 392 & 1.1 \\
\hline BCP ALL 6 & 706 & ND & ND & ND & 16,662 & 23.6 \\
\hline Sac-B 1 & 2,619 & 4,768 & ND & 7,428 & 13,049 & 5.0 \\
\hline Sac-B 2 & 1,152 & 3,637 & ND & 5,255 & 10,717 & 9.3 \\
\hline Sac-B 3 & 526 & 1,471 & ND & 1,965 & 2,444 & 4.7 \\
\hline Sac-B 4 & 98 & 296 & ND & 1,225 & 1,930 & 19.7 \\
\hline Sac-B 5 & 1,810 & 3,048 & ND & 4,698 & 6,078 & 3.4 \\
\hline Sac-B 6 & 1,758 & ND & ND & ND & 22,952 & 13.1 \\
\hline Sac-B 7 & 8,422 & ND & ND & ND & 13,145 & 1.6 \\
\hline Anti- $\mu$-B 6 & 846 & ND & ND & ND & 12,950 & 15.3 \\
\hline Anti- $\mu$-B 7 & 186 & ND & ND & ND & 12,467 & 67.0 \\
\hline Resting-B 6 & 496 & ND & ND & ND & 714 & 1.4 \\
\hline Resting-B 7 & 455 & ND & ND & ND & 521 & 1.1 \\
\hline
\end{tabular}

The effects of HMW-BCGF on $\left[{ }^{3} \mathrm{H}\right] \mathrm{TdR}$ incorporation by leukemic and normal $B$ cells was evaluated as previously described $(7,8,12,17)$. Data are expressed as the mean cpm incorporated by duplicate samples of $2 \times 10^{5}$ cells during the final $16 \mathrm{~h}$ of a 72 -h culture period in the presence of HMW-BCGF The maximum stimulation indices were determined from the ratios of the amounts of $\left[{ }^{3} \mathrm{H}\right] \mathrm{TdR}$ incorporation by HMW-BCGF stimulated cells to the amounts of $\left[{ }^{3} \mathrm{H}\right] \mathrm{TdR}$ incorporation by unstimulated cells. CLL, HCL, PLL, BCP ALL cells were obtained from patients before chemotherapy. Normal Bcells were purified from tonsils as previously described $(7,8,17)$ and assayed

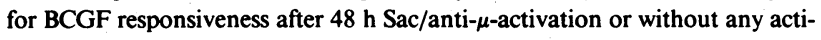
vation.

indices ranging from 1.6 to 67.0 (mean $\pm \mathrm{SE}=15.5 \pm 6.8$ ), whereas resting $B$ cells failed to respond to HMW-BCGF (Table II). The HMW-BCGF responsiveness of BCP-ALL cells and normal $B$ cells were consistent with previous reports on HMW-BCGF R expression on leukemic BCPs (10-12) and normal $B$ cells $(8,17)$. In addition, the ability of CLL, HCL, and PLL cells to respond to HMW-BCGF provided initial suggestive evidence for the constitutive expression of functional HMW-BCGF $R$ on these leukemic B cell populations. Since $\left[{ }^{3} \mathrm{H}\right] \mathrm{TdR}$ incorporation assays alone may not accurately reflect the proliferative activity of human lymphoid cells (12), we also studied the growth stimulatory effects of HMW-BCGF on CLL cells in a colony assay system.

Proliferative responses of clonogenic CLL cells to HMW$B C G F$. The proliferative responses of clonogenic CLL cells to HMW-BCGF are detailed on Table III. Spontaneous colony 
A. Proliferative responses of clonogenic CLL cells to HMW-BCGF

\begin{tabular}{|c|c|c|c|c|c|c|c|c|c|}
\hline \multirow[b]{3}{*}{ CLL No. } & \multirow{3}{*}{$\begin{array}{l}\text { No growth } \\
\text { factor }\end{array}$} & \multicolumn{8}{|c|}{ Mean No. of CLL colonies per $3 \times 10^{5}$ cells plated } \\
\hline & & \multicolumn{4}{|c|}{ HMW-BCGF (ng/ml) } & \multicolumn{4}{|c|}{ LMW-BCGF (ng/ml) } \\
\hline & & 0.2 & 1 & 2 & 4 & 0.2 & 1 & 2 & 4 \\
\hline 1 & 0 & 0 & 0 & 0 & 0 & $\longrightarrow$ & & . & \\
\hline 2 & 130 & 105 & 110 & 132 & 125 & 15 & 50 & 38 & 45 \\
\hline 3 & 12 & 596 & ND & 690 & 873 & 0 & 0 & 0 & 0 \\
\hline 4 & 19 & 22 & 9 & 29 & 17 & 0 & 0 & 0 & 0 \\
\hline 5 & $0(0)^{*}$ & 57 & 120 & 264 & $226(154)^{*}$ & 0 & 0 & 0 & 0 \\
\hline 6 & 0 & 23 & ND & 38 & 48 & 0 & 0 & 0 & 0 \\
\hline 7 & $0(0)^{*}$ & 516 & 607 & 930 & $1,003(423)^{*}$ & 777 & 1,081 & 1,134 & 1,144 \\
\hline 8 & 0 & 0 & 0 & 0 & 0 & 0 & 0 & 0 & 0 \\
\hline 9 & 0 & ND & 175 & 228 & 737 & 0 & 0 & 0 & 0 \\
\hline 10 & 0 & 31 & 69 & 482 & ND & 0 & 0 & 0 & 0 \\
\hline
\end{tabular}

B. Immunophenotypes of CLL colony cells in HMW-BCGF stimulated cultures

\begin{tabular}{|c|c|c|c|c|c|c|c|c|c|c|c|}
\hline \multirow[b]{3}{*}{ CLL No. } & \multicolumn{6}{|c|}{ Surface (cytoplasmic) Ig } & & & & & \\
\hline & \multicolumn{4}{|c|}{ Heavy chain } & \multicolumn{2}{|c|}{ Light chain } & \multicolumn{5}{|c|}{ Surface differentiation antigens } \\
\hline & $\mathbf{M}$ & D & A & G & $\mathbf{K}$ & $\lambda$ & CD3 & CD5 & CD19 & $\mathrm{CD} 20$ & BA5 \\
\hline 3 & $25(95)$ & 0 & 0 & 0 & 0 & $39(97)$ & 0 & 35 & 95 & 97 & 58 \\
\hline 5 & 99 & 0 & 0 & 0 & 0 & 99 & 0 & 95 & 98 & 93 & 75 \\
\hline 7 & $58(98)$ & 45 & 0 & 0 & 95 & 0 & 1 & 98 & 99 & 99 & 85 \\
\hline 9 & $13(95)$ & 0 & 0 & 0 & 88 & 0 & 0 & 99 & 98 & 95 & 75 \\
\hline 10 & 100 & 0 & 0 & 0 & 0 & 100 & 0 & 95 & 100 & 100 & 62 \\
\hline
\end{tabular}

The proliferative responses of clonogenic CLL cells to HMW-BCGF vs LMW-BCGF were evaluated in colony assays. Results are expressed as the mean number of CLL colonies per $3 \times 10^{5}$ cells plated in duplicated dishes. ${ }^{*}$ BA- $5^{+}$FACS sorted cells were used. ND: Not determined. The immunological marker profiles of colony cells were determined as described in Methods. Results are expressed as the percentage of colony cells positive for each marker.

formation in the absence of exogeneous growth factors was observed in three (CLLs 2-4) of 10 cases with a mean ( \pm SE) of $54 \pm 38$ colonies $/ 3 \times 10^{5}$ CLL cells plated. HMW-BCGF stimulated CLL colony formation in 6 (CLLs 3, 5-7, 9, 10) of 10 cases with a maximum (mean $\pm \mathrm{SE})$ of $510 \pm 168$ colonies $($ range $=48-1003) / 3 \times 10^{5} \mathrm{CLL}$ cells $($ Table III), indicating that clonogenic leukemic cells in CLL express functional $R$ for HMW-BCGF. Table III $B$ details the immunological marker profiles of clonal leukemic B cell populations in HMW-BCGF stimulated cultures of CLL cells. The in situ morphology of day 7 colonies, the morphology as well as immunophenotype of colony cells in HMW-BCGF stimulated cultures from a representative case (CLL 5) are shown in Fig. 2. The composite immunophenotypes of colony cells were identical to those of uncultured fresh CLL cells, confirming their leukemic origin, B lineage affiliation, and clonality (Table III). The pooled CLL colony cell preparations were devoid of $T$ lymphocyte contamination, as evidenced by their lack of CD3 antigen, as well as normal B lymphocyte contamination, as evidenced by their clonal surface/cytoplasmic Ig profiles combined with co-expression of CD5 antigen. Notably, $71 \pm 5 \%$ (range $=58-85 \%$ ) of colony cells were $\mathrm{HMW}-\mathrm{BCGF} \mathrm{R}^{+}$, as determined by reactivity with BA-5 MAb (Table III, Fig. 2). In contrast to HMWBCGF, LMW-BCGF stimulated CLL colony formation only in one (CLL 7) of 9 cases analyzed. In three CLL cases with spontaneous colony formation, LMW-BCGF was inhibitory and in the remaining six CLL cases it failed to stimulate colony formation (Table III).

We also used virtually pure populations of BA $-5^{+}$FACS sorted CLL cells from two HMW-BCGF responsive cases (CLLs 5 and 7) to preclude accessory cells from affecting the HMW-BCGF responses of CLL cells (Table III). The light scattering contour plots, BA-5 reactivity, and the windows used for sorting are shown in Fig. 3. In both cases, HMWBCGF stimulated the proliferative activity of FACS sorted BA $-5^{+}$clonogenic CLL cells. These findings establish that HMW-BCGF exerts a direct stimulatory effect on clonogenic CLL cells that does not require the presence of HMW-BCGF $\mathbf{R}^{-}$accessory cell populations.

$B$-lineage CLL cells constitutively express functional $R$ for human $H M W-B C G F$. The proliferative responses of leukemic CLL B cells to HMW-BCGF in $\left[{ }^{3} \mathrm{H}\right] \mathrm{TdR}$ incorporation and colony assays provided circumstantial evidence for their expression of functional HMW-BCGF R. To provide direct and conclusive evidence for the constitutive expression of HMWBCGF $R$ on CLL cells, we investigated the binding of ${ }^{125} \mathrm{I}$ HMW-BCGF to fresh leukemic cells from 10 CLL patients in the presence and absence of excess cold HMW-BCGF (Table 

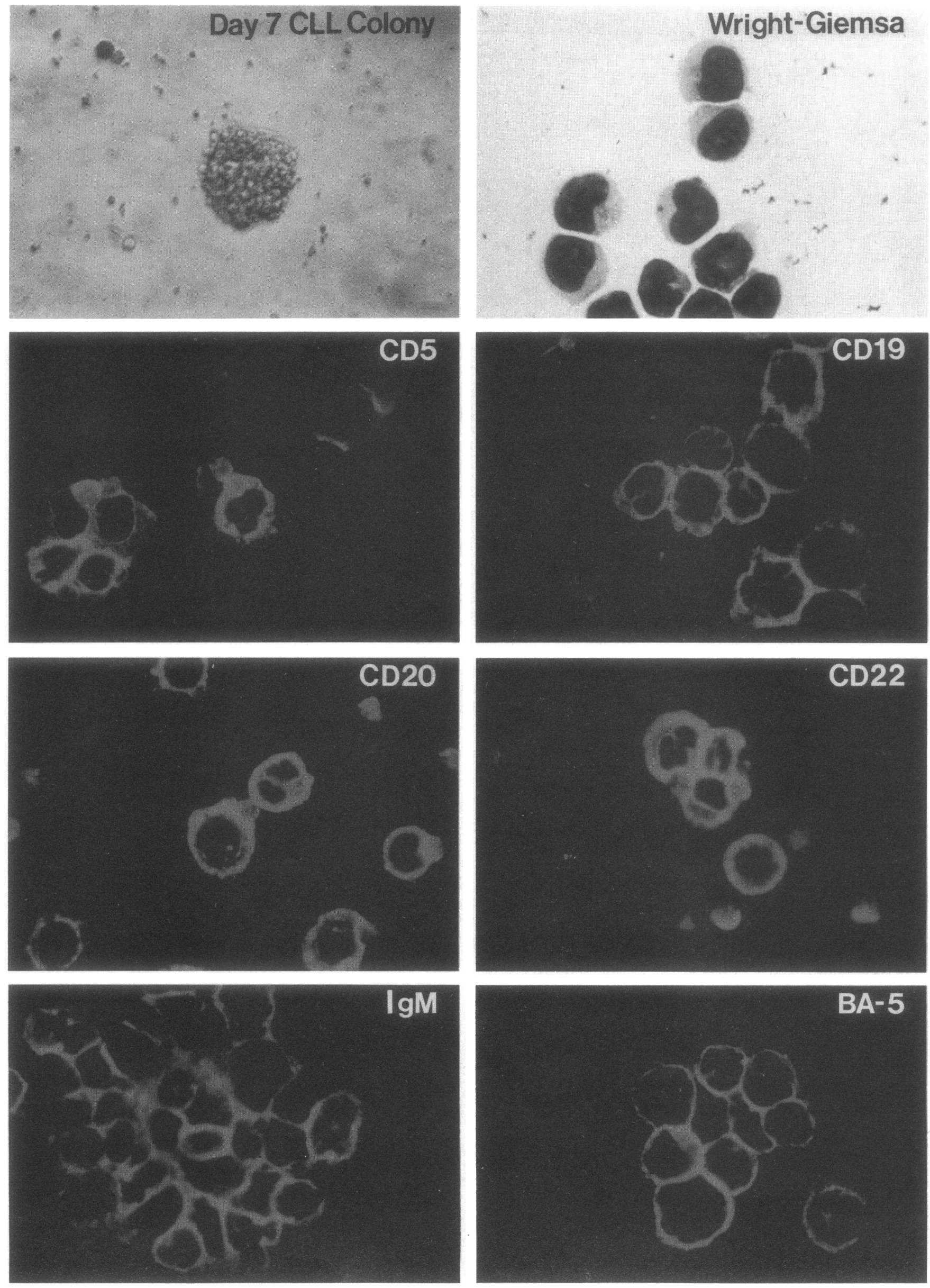
IV). A marked interpatient variation in the amount of specific binding of ${ }^{125} \mathrm{I}$-HMW-BCGF to CLL cells was observed. In 6 (CLLs 3, 5, 6, 7, 9, 10) of 10 cases $(60 \%)$, the binding of ${ }^{125}$ I-HMW-BCGF was $\geq 20 \%$ (range 20\% [CLL 10]-81\% [CLL 7]) blocked by excess cold HMW-BCGF (Table IV). In these 6 cases, the cell-bound radioactivity ranged from $180 \mathrm{cpm} / 10^{6}$ cells (CLL 10) to $740 \mathrm{cpm} / 10^{6}$ cells (CLL 9) (mean \pm SE $=371.5 \pm 98.9 \mathrm{cpm} / 10^{6}$ cells), indicating that $1.4-7.4 \mathrm{fmol}$ (mean $\pm \mathrm{SE}=3.7 \pm 1.0)$ of ${ }^{125} \mathrm{I}$-HMW-BCGF were bound per $10^{6} \mathrm{CLL}$ cells. The estimated number of ${ }^{125}$ I-HMW-BCGF molecules bound per cell in these 6 cases ranged from 828 (UPN 6) to 4,440 (UPN 9) (mean $\pm \mathrm{SE}=2,229 \pm 593$ ) (Table II). In all six cases with significant HMW-BCGF binding, $\left[{ }^{3} \mathrm{H}\right] \mathrm{TdR}$ incorporation and/or colony formation by CLL cells was stimulated by HMW-BCGF (Tables II-IV). In contrast, no stimulation was observed in four cases that showed no significant ${ }^{125}$ I-HMW-BCGF binding (Tables II-IV). Hence, there was a high correlation between ${ }^{125}$ I-HMW-BCGF binding and HMW-BCGF responsiveness, indicating that functional HMW-BCGF $R$ were detected in ligand binding assays. Although $\mathrm{R}$ binding assays using a single concentration of ${ }^{125}$ I-HMW-BCGF or functional colony assays may not be sensitive enough to detect low levels of HMW-BCGF R expression, our findings provide direct evidence for constitutive expression of functional HMW-BCGF R on CLL cells. Since these binding assays were performed using a single concentration of the radiolabeled ligand, the presented results lack quantitative rigor and represent only a "crude" estimation of the actual number of HMW-BCGF R on the cell surface. Unfortunately, the limited amount of purified HMW-BCGF available together with the limited number of cells procured from each patient prohibited a more detailed and accurate analysis of HMW-BCGF $R$ expression in all cases. Recently, we reported a novel MAb, designated BA-5, which recognizes a 90-kD ligand binding site of HMW-BCGF $R$ on human B lineage cells (17). We next used this anti-HMW-BCGF R MAb to detect HMW-BCGF binding sites on leukemic cells from 18 CLL patients (CLL 1-CLL 18) by immunofluorescence and flow cytometry. Four representative CLL cases are shown in Fig. $4 \mathrm{~A}$. The percent positivity correlated with ${ }^{125} \mathrm{I}-\mathrm{HMW}$ BCGF binding as well as HMW-BCGF responsiveness in colony assays (Table IV). Only $1-4 \%$ (mean $\pm \mathrm{SE}=2 \pm 1 \%$ ) of cells in HMW-BCGF $\mathrm{R}^{-} / \mathrm{HMW}$-BCGF unresponsive cases were $\mathrm{BA}^{+} 5^{+}$whereas $47-74 \%($ mean $\pm \mathrm{SE}=63 \pm 4 \%)$ of cells in HMW-BCGF $\mathrm{R}^{+} / \mathrm{HMW}-\mathrm{BCGF}$ responsive cases reacted with BA-5 MAb $(P<0.001)$.

Similar to CLL cells, also leukemic cells from three of four HCL cases expressed HMW-BCGF R, consistent with their ability to respond to HMW-BCGF with increased $\left[{ }^{3} \mathrm{H}\right] \mathrm{TdR}$ incorporation (Table IV). The percent inhibitable ${ }^{125} \mathrm{I}-\mathrm{HMW}$ BCGF binding in these three HMW-BCGF responsive HCL cases ranged from $38 \%$ (HCL 1) to $43 \%$ (HCL 4). 4.2 (HCL 1) -45.2 (HCL 4) fmol $/ 10^{6}$ cells (mean $\pm \mathrm{SE}=22.1 \pm 12.1$ $\mathrm{fmol} / 10^{6}$ cells) $(=13,274 \pm 7,269$ molecules/cell $)$ of ${ }^{125} \mathrm{I}$-HMWBCGF were specifically bound to HCL cells. The percent BA-5 positivity in these three cases ranged from $25 \%$ to $65 \%$ (Table
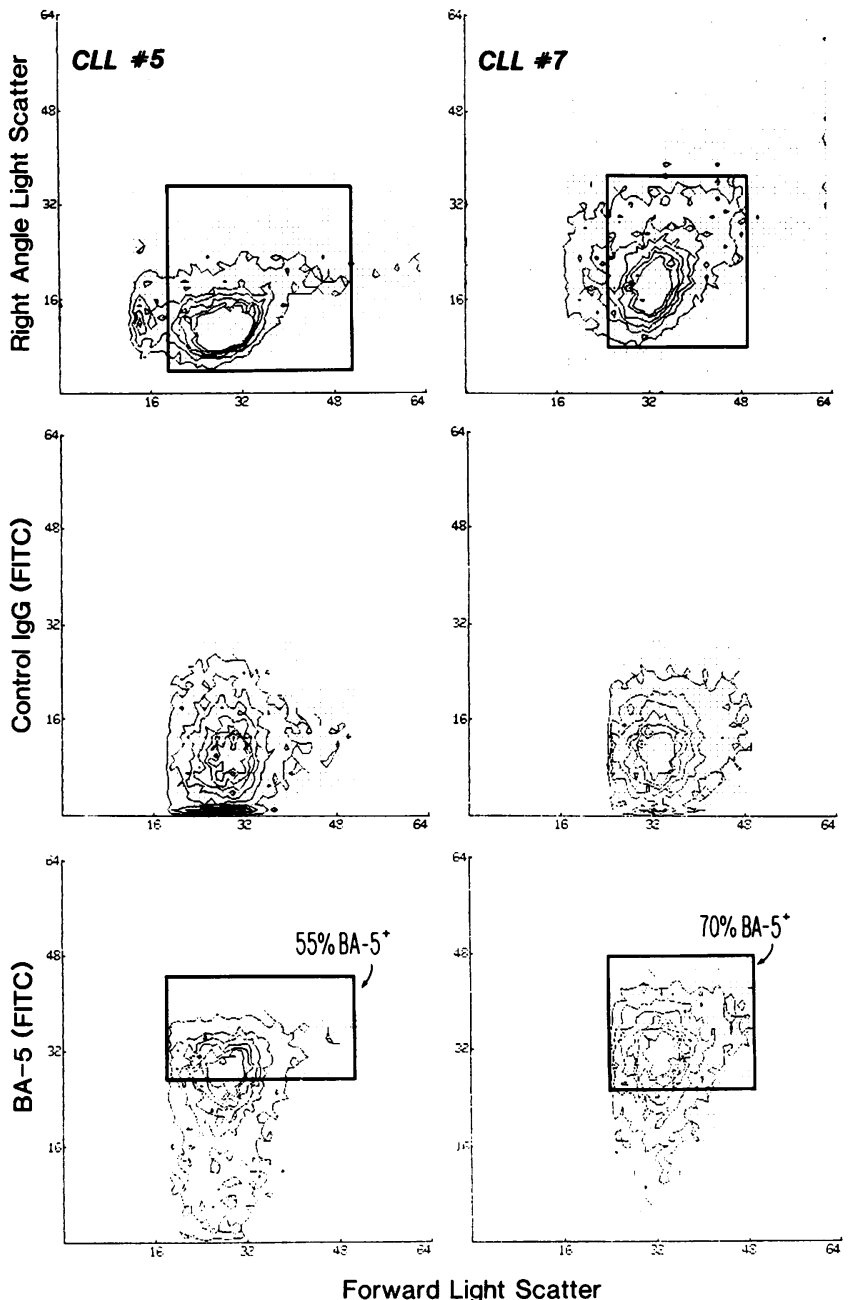

Figure 3. FACS sorting of BA-5 positive CLL cells. Fresh CLL cells from CLL 5 and CLL 7 were stained for surface HMW-BCGF R using BA-5 MAb. Boxes in the light scattering contour plots identify the gates used to reanalyze the list mode data for identifying BA-5 positive CLL cells. Boxes on the FACS correlated forward light scatter versus BA-5 FITC displays of gated CLL cells identify the windows used for sorting the BA-5 positive CLL cells.

IV). By comparison, HMW-BCGF unresponsive leukemic cells from HCL 2 did not bind ${ }^{125}$ I-HMW-BCGF in ligand binding assays and only $5 \%$ of cells displayed above-background immunofluorescence when stained with BA-5 MAb. Fig. $4 B$ shows FACS-correlated two-parameter displays of HMW-BCGF responsive leukemic cells from HCL 4 which were two-color stained with BA-5 (FITC/green) and B43 (PE/ orange-red) MAb. These immunofluorescence data, taken together with the ${ }^{125}$ I-HMW-BCGF binding data, are direct and conclusive evidence that a significant fraction of $\mathrm{CD} 19^{+}$leukemic cells in HMW-BCGF-responsive HCL cases express HMW-BCGF R. A significant fraction of CD19+ PLL cells were also BA- $5^{+}$(Fig. $4 \mathrm{~B}$ ). By comparison, $5.1-8.3 \%$ of nor-

Figure 2. HMW-BCGF-stimulated CLL colony formation. Fresh CLL cells from CLL 5 were cultured in the presence of $4 \mathrm{ng} / \mathrm{ml} \mathrm{HMW}-\mathrm{BCGF}$ and assayed for in vitro colony formation. Colony cells were analyzed as described in Methods. The morphologic and immunophenotypic features of colony cells were consistent with CLL. See also Table III for more details on the immunological marker profiles of CLL colony cells. 
mal peripheral blood mononuclear cells were $\mathrm{CD} 19^{+} \mathrm{BA}-5^{+}$. This HMW-BCGF $\mathrm{R}^{+}$fraction represented $77-82 \%$ of $\mathrm{CD}_{19}{ }^{+}$ $B$ cells in the peripheral blood.

We also examined the binding of ${ }^{125} \mathrm{I}-\mathrm{HMW}-\mathrm{BCGF}$ to $(a)$ Sac-activated as well as resting purified normal B cells, (b) EBV transformed B lymphoblasts of the Marbrook cell line, and $(c)$ resting T cells. As shown in Table IV, Sac activated B cells expressed HMW-BCGF $R$ and the percent inhibitable binding of ${ }^{125} \mathrm{I}-\mathrm{HMW}-\mathrm{BCGF}$ ranged from $54 \%$ to $87 \%$. 2.9-31.4 fmol $/ 10^{6}$ cells $(=1,752-18,858$ molecules/cell) of ${ }^{125}$ I-HMW-BCGF was specifically bound to these cells which (a) displayed $40-60 \%$ positivity when stained with BA-5 antibody and $(b)$ responded to HMW-BCGF in $\left[{ }^{3} \mathrm{H}\right] \mathrm{TdR}$ incorporation assays (see Table II). Similarly, Marbrook cells showed $60 \%$ inhibitable binding of ${ }^{125} \mathrm{I}-\mathrm{HMW}-\mathrm{BCGF}$ with $12 \mathrm{fmol}$ of HMW-BCGF bound per $10^{6}$ cells $(=7,170$ molecules/cells). The proliferative response of Marbrook cells to HMW-BCGF could not be accurately determined because of their very high proliferative activity in the absence of HMW-BCGF. By comparison, resting tonsillary $B$ cells bound $0.0-0.6 \mathrm{fmol} / 10^{6}$ cells (=0-384 molecules/cell) of ${ }^{125} \mathrm{I}-\mathrm{HMW}-\mathrm{BCGF}$ and unlike activated $B$ cells, they did not respond to HMW-BCGF with increased $\left[{ }^{3} \mathrm{H}\right] \mathrm{TdR}$ incorporation (Tables II, IV). Resting $\mathrm{T}$ cells did not exhibit any significant specific ${ }^{125}$ I-HMW-BCGF binding (Table IV).

Table $\mathrm{V}$ demonstrates the effects of the anti-HMW-BCGF R MAb BA-5 on HMW-BCGF induced proliferation of Sacactivated normal B cells. Sac-activated B cells responded in a dose-dependent fashion to $0.4-4.0 \mathrm{ng} / \mathrm{ml} \mathrm{HMW-BCGF}$ with increased $\left[{ }^{3} \mathrm{H}\right] \mathrm{TdR}$ incorporation. In accordance with our previous findings (17), BA-5 MAb $(0.1 \mu \mathrm{g} / \mathrm{ml}-10 \mu \mathrm{g} / \mathrm{ml})$ inhibited the proliferative response of Sac-activated B-cells whereas the control murine IgG P3X antibody had very little effect. We next studied the effects of BA-5 MAb on HMW-BCGF induced proliferation of clonogenic CLL cells from three cases. BA-5 MAb inhibited HMW-BCGF response but it did not affect the LMW-BCGF response of CLL cells (Table V). In contrast to BA-5, anti-Tac (anti-IL-2 R) MAb did not affect HMW-BCGF or LMW-BCGF stimulated CLL colony formation. Thus, BA-5 MAb was able to specifically disrupt HMWBCGF/HMW-BCGF $\mathbf{R}$ interactions at the level of clonogenic CLL cells. These findings provide corroborative evidence that HMW-BCGF exerts stimulatory effects on CLL cells via the HMW-BCGF $R$ recognized by BA-5 MAb.

Characterization of HMW-BCGF R on CLL cells by Scatchard analysis. As mentioned earlier, the limited amounts of purified HMW-BCGF prohibited detailed equilibrium binding assays using ${ }^{125} \mathrm{I}-\mathrm{HMW}-\mathrm{BCGF}$. Since BA-5 MAb reacts with the ligand binding site of HMW-BCGF R (17), we decided to use ${ }^{125} \mathrm{I}-\mathrm{BA}-5$ as a HMW-BCGF R-specific probe for further characterization of HMW-BCGF R. Equilibrium binding assays were performed on cryopreserved leukemic $B$ cells from one HMW-BCGF responsive CLL test case (CLL 9) and two HMW-BCGF unresponsive CLL controls (CLL 1 and CLL 4) using ${ }^{125} \mathrm{I}$-labeled $\mathrm{BA}-5 \mathrm{MAb}$ as a HMW-BCGF R-specific probe. Fig. 5 illustrates the binding of ${ }^{125} \mathrm{I}-\mathrm{BA}-5$ to CLL cells as a function of the concentration of ${ }^{125} \mathrm{I}-\mathrm{BA}-5$ in the binding medium. ${ }^{125}$ I-BA-5 exhibited specific binding to CLL 9 cells which was saturable at higher concentrations of the radiolabeled ligand. The percent inhibitable (= specific) binding ranged from $45.8 \%\left(130 \mathrm{cpm} / 10^{7}\right.$ cells of a total of 284 $\mathrm{cpm} / 10^{7}$ cells $)$ at $5 \times 10^{-10} \mathrm{M}$ to $77.4 \%\left(1,510 \mathrm{cpm} / 10^{7}\right.$ cells of
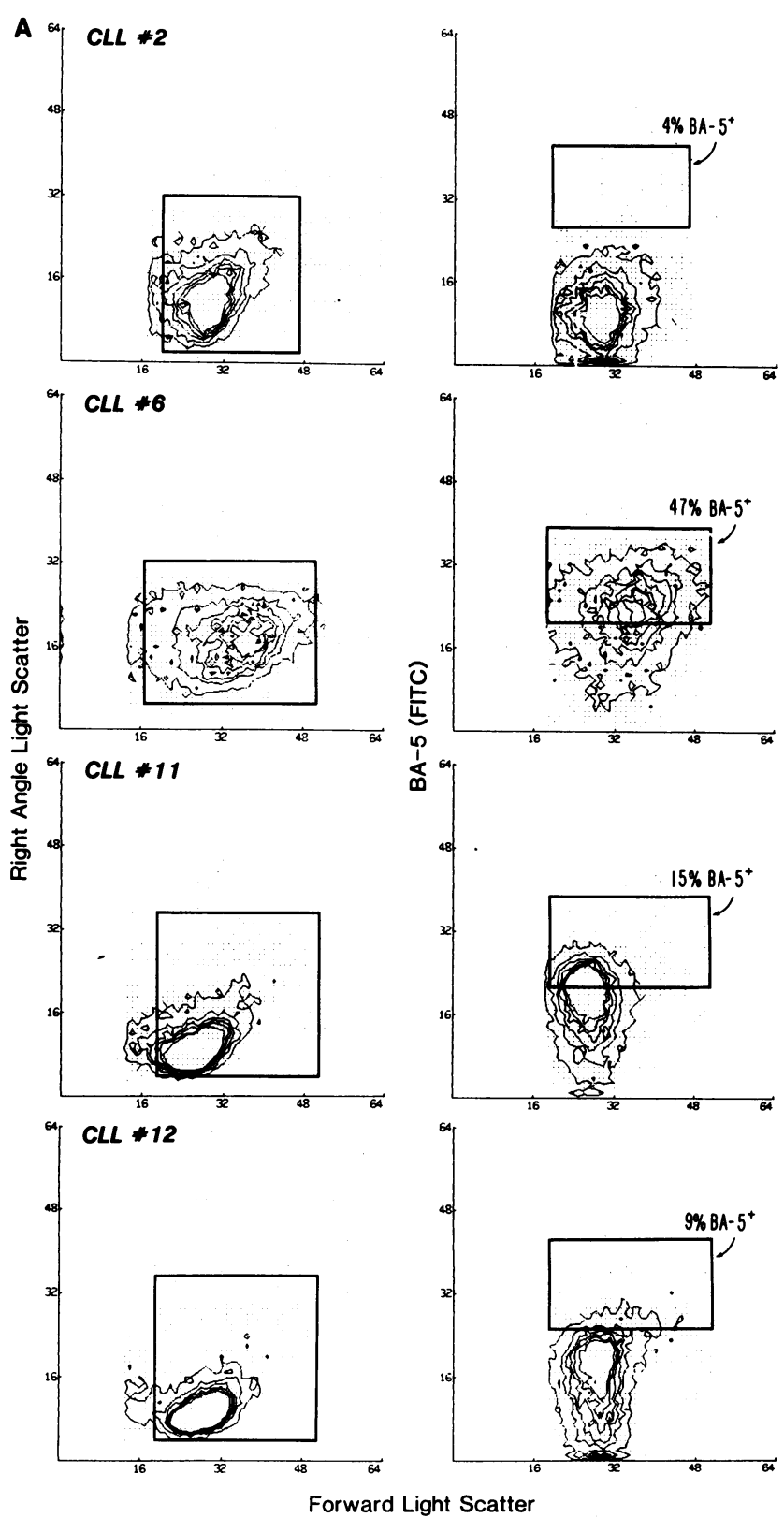

Figure 4. Multiparameter flow cytometric analysis of CLL, HCL, PLL, and normal peripheral blood (PB) B Cells stained with BA-5, anti-HMW-BCGF R MAb. (A) The forward angle and right angle light scattering contour plots as well as BA-5 reactivity for CLL cells within the indicated light scattering window are shown for four representative CLL cases. Boxes in the light scattering contour plots identify the gates used to reanalyze the list mode data for determining the expression of HMW-BCGF R on CLL cells. The boxes on the FACS correlated forward angle light scatter versus BA-5 (FITC) displays were set using appropriate negative controls. (B) HCL, PLL, and normal peripheral blood (PB) mononuclear cells were two-color stained with B43/CD19-PE and BA-5-FITC. Boxes in the light scattering contour plots identify the gates used to reanalyze the list mode data for determining the correlated expression of CD19 and HMWBCGF-R on HCL, PLL, and normal PB mononuclear cells.

a total of $1,952 \mathrm{cpm} / 10^{7}$ cells) at $5 \times 10^{-9} \mathrm{M}$ (median $=66.6 \%$ at $1 \times 10^{-7} \mathrm{M} ; 6,329 \mathrm{cpm} / 10^{7}$ cells of a total of $9,508 \mathrm{cpm} / 10^{7}$ cells). The specific activity of ${ }^{125} \mathrm{I}-\mathrm{BA}-5$ was $1.5 \times 10^{17} \mathrm{cpm} /$ 

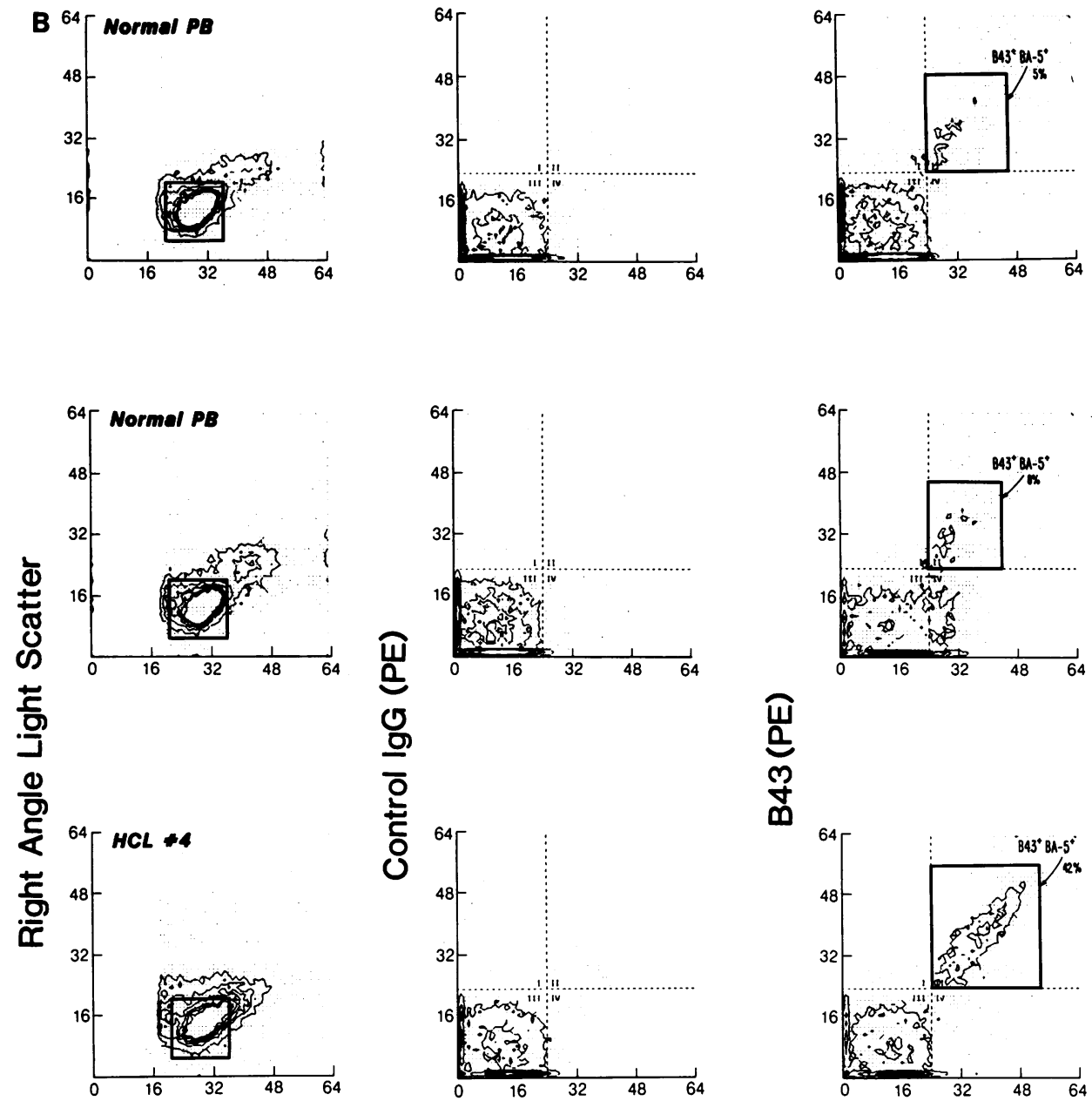

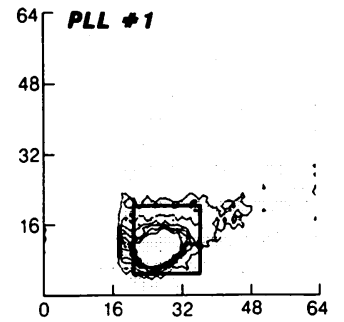

Forward Light Scatter

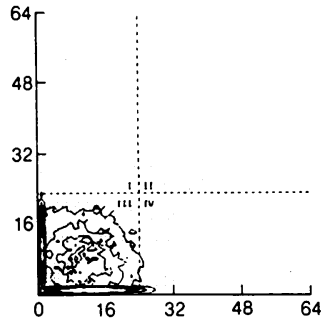

Control IgG (FITC)

mol; hence $10 \mathrm{cpm}$ associated with $10^{7}$ cells and inhibitable by excess cold BA-5 corresponded to four molecules of ${ }^{125}$ I-BA-5 specifically bound to each cell. Scatchard plot analysis of the specific equilibrium binding data yielded a straight linear regression line, indicating the existence of a single class of HMW-BCGF R. The apparent affinity constant $\left(K_{\mathrm{a}}\right)$ was 4.6 $\times 10^{7} \mathrm{M}^{-1}$ and there were $\sim 3,000 \mathrm{HMW}-\mathrm{BCGF} \mathrm{R} /$ cell. It should be noted that Scatchard analyses provide only estimations of the "average" receptor numbers based on the assumption that every cell $(100 \%)$ in the target cell population expresses the respective growth factor receptor (33). Since only $0.246 \%$ (737 HMW-BCGF responsive clonogenic cells/ 300,000 cells plated) of CLL 9 cells showed a proliferative response to HMW-BCGF, it is a distinct possibility that only this small fraction of malignant B cells from CLL 9 expressed

functional HMW-BCGF R. In this case, the number of HMW-BCGF $R$ on the HMW-BCGF responsive population of CLL 9 cells could be as high as $1.2 \times 10^{6}$ receptors/cell which is $\sim 400$-fold higher than the Scatchard based value of 3,000 receptors/cell. The authors also appreciate that these results obtained using CLL 9 cells may not be applicable to all CLLs. The negative inverse of the regression coefficient yielded a dissociation constant $\left(K_{\mathrm{d}}\right)$ of $20 \mathrm{nM}$. By comparison, the concentration of HMW-BCGF to elicit a maximum proliferative response of CLL cells ranged from $2 \mathrm{ng} / \mathrm{ml}(0.033 \mathrm{nM})$ to $4 \mathrm{ng} / \mathrm{ml}(=0.066 \mathrm{nM})$ (see Tables II and III). Thus, the concentration of HMW-BCGF required for half-maximal receptor occupancy appears to be 300-600-fold higher than the concentrations of HMW-BCGF required to elicit maximum stimulation of CLL cells, indicating that only a small fraction 


\begin{tabular}{|c|c|c|c|c|c|c|c|c|}
\hline \multirow[b]{2}{*}{ CLL No. } & \multicolumn{6}{|c|}{${ }^{125} \mathrm{I}$-HMW-BCGF binding to $10^{6} \mathrm{CLL}$ cells } & \multirow[b]{2}{*}{$\begin{array}{l}\% \text { BA-5 } \\
\text { Positive }\end{array}$} & \multirow[b]{2}{*}{$\begin{array}{l}\text { Stimulation } \\
\text { (Yes/No) }\end{array}$} \\
\hline & $\begin{array}{c}\text { - cold } \\
\text { HMW-BCGF }\end{array}$ & $\begin{array}{l}+ \text { cold } \\
\text { HMW-BCGF }\end{array}$ & $\begin{array}{l}\text { Specific } \\
\text { binding }\end{array}$ & $\begin{array}{l}\text { Inhibitable } \\
\text { binding }\end{array}$ & $\mathrm{fmol} / 10^{6}$ cells & $\begin{array}{l}\text { Molecules } \\
\text { per cell }\end{array}$ & & \\
\hline & \multicolumn{3}{|c|}{ cpm } & \multicolumn{2}{|l|}{$\%$} & & & \\
\hline 1 & 1,010 & 1,030 & 0 & 0 & 0.0 & 0 & 2 & No \\
\hline 2 & 920 & 850 & 70 & 8 & 0.7 & 420 & 4 & No \\
\hline 3 & 590 & 375 & 215 & 36 & 2.2 & 1,290 & 63 & Yes \\
\hline 4 & 880 & 940 & 0 & 0 & 0.0 & 0 & 2 & No \\
\hline 5 & 1,390 & 1,010 & 380 & 27 & 3.8 & 2,280 & 55 & Yes \\
\hline 6 & 625 & 487 & 138 & 22 & 1.4 & 828 & 47 & Yes \\
\hline 7 & 709 & 133 & 576 & 81 & 5.8 & 3,456 & 70 & Yes \\
\hline 8 & 492 & 405 & 87 & 18 & 0.9 & 522 & 1 & No \\
\hline 9 & 1,720 & 980 & 740 & 43 & 7.4 & 4,440 & 74 & Yes \\
\hline 10 & 910 & 730 & 180 & 20 & 1.8 & 1,080 & 70 & Yes \\
\hline \multicolumn{2}{|l|}{ HCL No. } & \multicolumn{4}{|c|}{${ }^{125} \mathrm{I}$-HMW-BCGF binding to $10^{6} \mathrm{HCL}$ cells } & & & \\
\hline 1 & 1,111 & 690 & 421 & 38 & 4.2 & 2,526 & 65 & Yes \\
\hline 2 & 707 & 751 & 0 & 0 & 0.0 & 0 & 5 & No \\
\hline 3 & 3,276 & 1,920 & 1,356 & 41 & 17.0 & 10,170 & 25 & Yes \\
\hline 4 & 8,493 & 4,876 & 3,617 & 43 & 45.2 & 27,127 & 45 & Yes \\
\hline Normal controls & \multicolumn{6}{|c|}{${ }^{125}$ I-HMW-BCGF binding to $10^{6}$ normal lymphocytes } & & \\
\hline Sac-Activated B 1 & 3,601 & 458 & 3,143 & 87 & 31.4 & 18,858 & 60 & Yes \\
\hline Sac-Activated B 2 & 540 & 248 & 292 & 54 & 2.9 & 1,752 & 40 & Yes \\
\hline Marbrook(EBV-BLCL) & 1,986 & 791 & 1,195 & 60 & 12.0 & 7,170 & 75 & $\mathrm{ND}^{*}$ \\
\hline Resting B 6 & 198 & 134 & 64 & 32 & 0.6 & 384 & 7 & No \\
\hline Resting B 7 & 108 & 116 & 0 & 0 & 0.0 & 0 & 2 & No \\
\hline \multicolumn{9}{|l|}{ Resting T } \\
\hline (Peripheral blood) & 15 & 20 & 0 & 0 & 0.0 & 0 & 0 & No \\
\hline
\end{tabular}

HMW-BCGF R binding and function studies on CLL cells were performed using ${ }^{125} \mathrm{I}-\mathrm{HMW}$-BCGF and CLL colony assays [ $\left.{ }^{3} \mathrm{H}\right] \mathrm{TdR}$ incorporation assays as described in Methods. Each cpm determination was performed in duplicate. The maximum variation of cpm in replicate samples did not exceed $25 \%$ of the mean cpm. The reactivity of BA-5 (anti-HMW-BCGF R) MAb with cells was tested by indirect immunofluorescence and flow cytometry and the results are expressed as the percentage of BA-5 $5^{+}$cells in each CLL case. Controls included HCL cells from four patients, Sac-activated tonsillary B-cells from two individuals, resting tonsillary B cells from two normal donors and resting peripheral blood T cells from one normal donor and the EBV-transformed B-lymphoblastoid cell line Marbrook. Stimulation of HCL cells, Sac-activated B cells, resting B/T cells was measured using $\left[{ }^{3} \mathrm{H}\right] \mathrm{TdR}$ incorporation assays as described in Methods. For details, see Tables II and III.* The proliferative response of Marbrook cells to HMW-BCGF could not be accurately determined because of their very high proliferative activity in the absence of HMW-BCGF.

of HMW-BCGF R need to be occupied to stimulate CLL cells. This discrepancy between the ligand concentration required for half-maximal receptor occupancy vs the ligand concentration required for maximum stimulation is a common feature of many growth factor receptors on human hematopoietic cells $(33,34)$. The calculated $K_{\mathrm{d}}$ value of $20 \mathrm{nM}$ is much higher than the reported $K_{\mathrm{d}}$ values for some of the other hematopoietic growth factor receptors, such as IL-1 R on BCPs $\left(K_{\mathrm{d}}=83-190\right.$ pM) (33) or IL-3 R on BCPs (168-280 pM) (34), indicating that either $(a)$ HMW-BCGF $\mathbf{R}$ are lower affinity $\mathbf{R}$ than IL-1 R or IL-3R, or $(b)$ the affinity of BA-5 MAb for HMW-BCGF R may be lower than the affinity of the natural ligand. Unlike CLL 9 cells, HMW-BCGF unresponsive leukemic-B cells from the control cases CLL 1 and CLL 4 exhibited no specific binding of ${ }^{125}$ I-BA-5. In CLL 1 , the percent inhibitable binding ranged from $0 \%$ at $1 \times 10^{-9} \mathrm{M}$ to $4.7 \%$ at $1 \times 10^{-7} \mathrm{M}$. The number of ${ }^{125}$ I-BA- 5 molecules bound per cell were only 89 at $1 \times 10^{-7} \mathrm{M}$. In CLL 4, the percent inhibitable binding ranged from $0 \%$ at $1 \times 10^{-9} \mathrm{M}$ to $10.8 \%$ at $1 \times 10^{-7} \mathrm{M}$ with only 65 molecules of ${ }^{125} \mathrm{I}$-BA- 5 bound per cell at $1 \times 10^{-7} \mathrm{M}$.

Affinity crosslinking of ${ }^{125} I-H M W-B C G F$ to $C L L$ cells. Figure 6 shows an SDS-PAGE analysis of plasma membrane proteins isolated by sonication and differential centrifugation from SAC activated normal tonsillary B cells and leukemic B cells from two HMW-BCGF responsive CLL cases that were incubated with ${ }^{125} \mathrm{I}$-HMW-BCGF in the presence and absence of unlabeled HMW-BCGF, washed, and exposed to the crosslinking agent DTSSP. ${ }^{125}$ I-HMW-BCGF had a molecular weight of $60 \mathrm{kDa}$ (Fig. 6, lanes 1 and 4) while the crosslinked HMW-BCGF/HMW-BCGF R complex on SAC activated normal B cells shown in lane 2 of Fig. 5 had an approximate molecular weight of $150 \mathrm{kD}$. ${ }^{125} \mathrm{I}-\mathrm{HMW}-\mathrm{BCGF}$ crosslinked to its binding site on leukemic CLL B cells also produced a 150 kD HMW-BCGF/HMW-BCGF R complex (Fig. 6, lanes 6 and 8). Subtracting the molecular weight of the crosslinked HMW-BCGF (60 kD), this suggests that the HMW-BCGF R is 


\begin{tabular}{|c|c|c|c|c|}
\hline \multirow[b]{2}{*}{ Growth factor } & \multirow[b]{2}{*}{ Antibody added } & \multicolumn{3}{|c|}{$\begin{array}{c}{\left[{ }^{3} \mathrm{H}\right]-\mathrm{TdR} \text { incorporation }(\mathrm{cpm}) / 2 \times 10^{5} \text { Sac-activated }} \\
\text { normal tonsillary B cells }\end{array}$} \\
\hline & & \multicolumn{2}{|c|}{ Experiment 1} & Experiment 2 \\
\hline \multirow{2}{*}{$\begin{array}{l}\text { None } \\
\text { HMW-BCGF } 0.4 \mathrm{ng} / \mathrm{ml}\end{array}$} & None & \multicolumn{2}{|c|}{$1,810 \pm 79$} & $3,189 \pm 23$ \\
\hline & None & \multicolumn{2}{|c|}{$3,048 \pm 40$} & $5,160 \pm 1,364$ \\
\hline $2.0 \mathrm{ng} / \mathrm{ml}$ & None & & & ND \\
\hline $4.0 \mathrm{ng} / \mathrm{ml}$ & None & & & $11,715 \pm 225$ \\
\hline $4.0 \mathrm{ng} / \mathrm{ml}$ & BA-5 $0.1 \mu \mathrm{g} / \mathrm{ml}$ & & & $11,465 \pm 1,287$ \\
\hline $4.0 \mathrm{ng} / \mathrm{ml}$ & BA-5 $1.0 \mu \mathrm{g} / \mathrm{ml}$ & & & $2,727 \pm 1,302$ \\
\hline $4.0 \mathrm{ng} / \mathrm{ml}$ & BA-5 $5.0 \mu \mathrm{g} / \mathrm{ml}$ & & & $1,593 \pm 442$ \\
\hline $4.0 \mathrm{ng} / \mathrm{ml}$ & BA-5 $10.0 \mu \mathrm{g} / \mathrm{ml}$ & & & $1,968 \pm 327$ \\
\hline \multirow[t]{3}{*}{$4.0 \mathrm{ng} / \mathrm{ml}$} & $\mathrm{P} 3 \times 1.0 \mu \mathrm{g} / \mathrm{ml}$ & & & ND \\
\hline & & \multicolumn{3}{|c|}{ CLL Colonies $/ 3 \times 10^{5}$ CLL cells plated } \\
\hline & & CLL 3 & $\operatorname{CLL} 7$ & CLL 10 \\
\hline None & None & 12 & 0 & 0 \\
\hline None & anti-TAC $25 \mu \mathrm{g} / \mathrm{ml}$ & 10 & 0 & 0 \\
\hline None & BA-5 $25 \mu \mathrm{g} / \mathrm{ml}$ & 15 & 0 & 0 \\
\hline HMW-BCGF $2 \mathrm{ng} / \mathrm{ml}$ & None & 355 & 645 & 125 \\
\hline $2 \mathrm{ng} / \mathrm{ml}$ & anti-TAC $25 \mu \mathrm{g} / \mathrm{ml}$ & 323 & 610 & 133 \\
\hline $2 \mathrm{ng} / \mathrm{ml}$ & BA-5 $25 \mu \mathrm{g} / \mathrm{ml}$ & 104 & 203 & 15 \\
\hline $4 \mathrm{ng} / \mathrm{ml}$ & None & 638 & 935 & 396 \\
\hline $4 \mathrm{ng} / \mathrm{ml}$ & anti-TAC $25 \mu \mathrm{g} / \mathrm{ml}$ & 601 & 987 & 379 \\
\hline $4 \mathrm{ng} / \mathrm{ml}$ & BA-5 $25 \mu \mathrm{g} / \mathrm{ml}$ & 197 & 258 & 38 \\
\hline LMW-BCGF 2 ng/ml & None & 0 & 505 & 0 \\
\hline $2 \mathrm{ng} / \mathrm{ml}$ & anti-TAC $25 \mu \mathrm{g} / \mathrm{ml}$ & 0 & 490 & 0 \\
\hline $2 \mathrm{ng} / \mathrm{ml}$ & BA-5 $25 \mu \mathrm{g} / \mathrm{ml}$ & 0 & 514 & 0 \\
\hline
\end{tabular}

The effects of BA-5 MAb on HMW-BCGF induced proliferation of leukemic CLL B cells and Sac-activated normal tonsillary B-cells were evaluated in colony assays and $\left[{ }^{3} \mathrm{H}\right]-\mathrm{TdR}$ incorporation assays, respectively, as described in Methods. Data are the mean number of CLL colonies in duplicate cultures of $3 \times 10^{5}$ cells plated and the mean $( \pm \mathrm{SD}) \mathrm{cpm}$ incorporated by $2 \times 10^{5}$ Sac-activated B cells that were cultured in triplicate.

$\sim 90 \mathrm{kD}$. Some uncrosslinked ${ }^{125} \mathrm{I}-\mathrm{HMW}-\mathrm{BCGF}$ was also present in these preparations as evidenced by the $60-\mathrm{kD}$ protein band seen in lanes 6 and 8 of Fig. 6. The crosslinking of ${ }^{125}$ I-HMW-BCGF to its receptors on normal activated B cells or leukemic CLL B cells was specific since unlabeled excess cold HMW-BCGF abolished the development of both $150 \mathrm{kD}$ crosslinked complex and $60 \mathrm{kD}$ uncrosslinked ${ }^{125} \mathrm{I}-\mathrm{HMW}$ BCGF bands on the gel (Fig. 6, lanes 3, 5, 8).

\section{Discussion}

In this study, we elucidated the functional properties and structural nature of plasma membrane $\mathrm{R}$ for human HMWBCGF on malignant B-lymphocytes from CLL patients using ${ }^{125}$ I labeled purified HMW-BCGF, BA-5 MAb reactive with the ligand binding site of HMW-BCGF R, $\left[{ }^{3} \mathrm{H}\right] \mathrm{TdR}$ incorporation assays, and an in vitro colony assay system. Functional HMW-BCGF R were detected on leukemic B cells from $60 \%$ of CLL cases. Scatchard analysis of equilibrium binding data in a HMW-BCGF responsive CLL case indicated the existence of a single class of $\sim 3,000 \mathrm{HMW}-\mathrm{BCGF} \mathrm{R}$ on HMW-BCGF responsive CLL cells with an apparent affinity constant of 4.6 $\times 10^{7} \mathrm{M}^{-1}$. Affinity crosslinking of ${ }^{125} \mathrm{I}-\mathrm{HMW}-\mathrm{BCGF}$ to fresh CLL cells yielded a $150-\mathrm{kD}$ R-ligand complex suggesting a
90-kD HMW-BCGF binding site. This study extends the earlier work on the expression and function of HMW-BCGF R on leukemic cells from B lineage ALL patients (10-12) and normal activated B cells $(8,17)$. The constitutive expression of functional HMW-BCGF R on CLL cells (1) suggests that HMW-BCGF may be involved in the clonal expansion of malignantly transformed B lymphocytes and (2) recommends future long-term studies of its role in leukemogenesis and disease progression in CLL. Our observation that not all CLLs expressed functional HMW-BCGF $R$ provides suggestive evidence that CLL may be a biologically heterogeneous group of diseases, which supports and extends the findings of Karray et al. (27), and Hivroz et al. (28). Whether or not biologically and prognostically distinct subgroups of patients can be identified based on HMW-BCGF $R$ expression will be the subject of separate long-term studies.

B lineage CLL represents clonal expansions of relatively mature B lymphocyte populations $(1,19)$. The putative normal counterparts of CLL cells are thought to be $\mathrm{CD} 5 / \mathrm{T}^{+} \mathrm{SIg}^{+} \mathrm{B}$ lymphocytes found in normal adult as well as fetal lymph nodes $(1,20,21)$. Freshly isolated B lineage CLL cells have been reported to have a very low proliferative activity (19) with more than $99 \%$ of cells in the $G_{0}$ phase of the cell cycle and $<0.1 \%$ in the S-phase (22) and are unresponsive to 


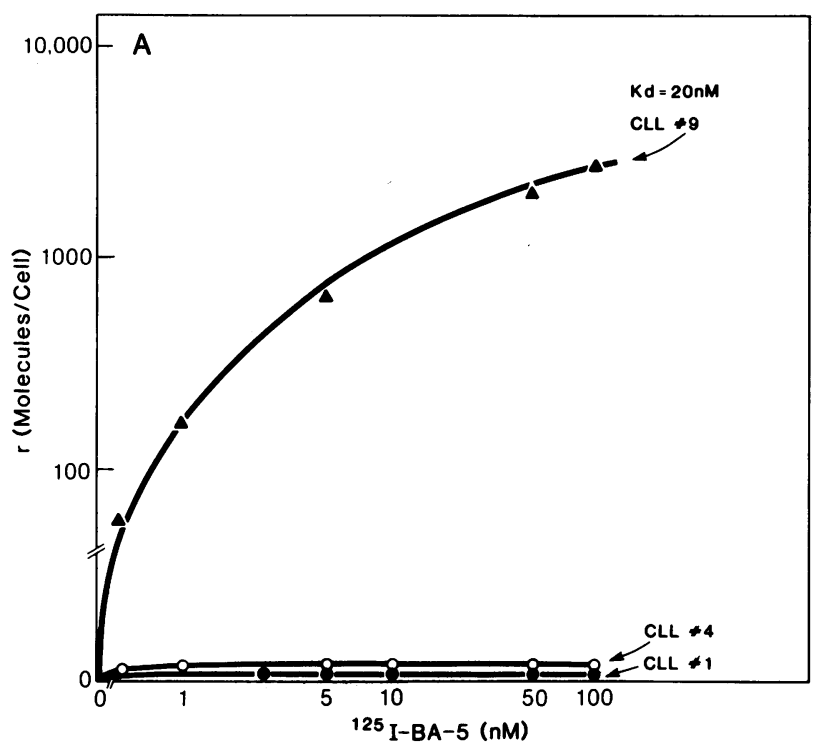

conventional B cell mitogens such as pokeweed mitogen and lipopolysaccharide. Several investigators analyzed the effects of LMW-BCGF on B lineage CLL cells in $\left[{ }^{3} \mathrm{H}\right] \mathrm{TdR}$ incorporation assays and found that unless triggered by the proper competence signals CLL cells do not respond to LMW BCGF (24-32) and even after activation they display an impaired responsiveness to LMW-BCGF (26). In the present study, we found that, with only one exception, none of the CLL cases responded to LMW-BCGF. Other GF that have been tested

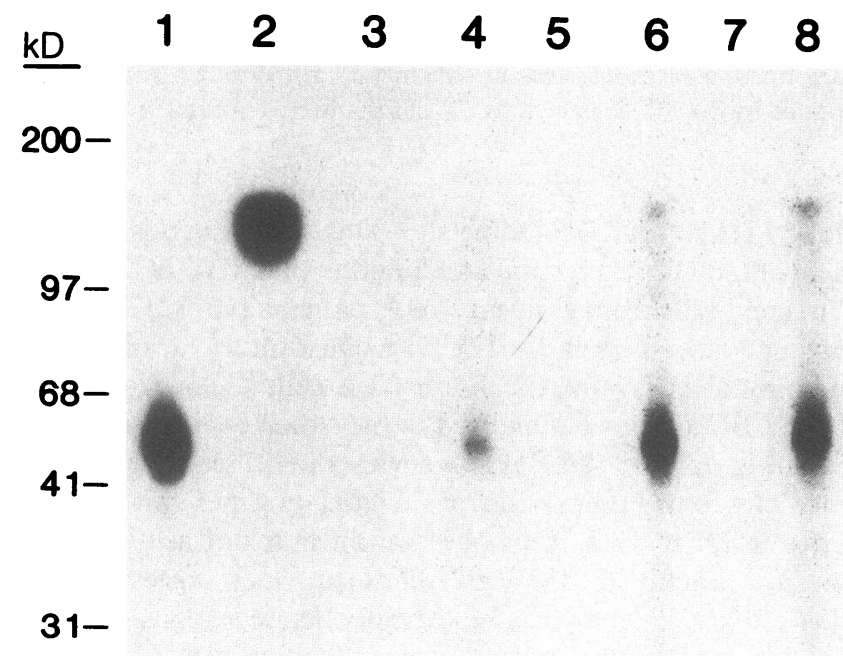

Figure 6. Structural nature of HMW-BCGF R on CLL cells. Affinity crosslinking of ${ }^{125}$ I-HMW-BCGF to leukemic B cells from CLL 6 and CLL 7 was performed as detailed in Methods. Lane 1: ${ }^{125} \mathrm{I}$ HMW-BCGF; lane 2: ${ }^{125} \mathrm{I}-\mathrm{HMW}-\mathrm{BCGF}$ crosslinked to its R on SACactivated tonsillary B cells; lane 3: ${ }^{125}$ I-HMW-BCGF crosslinked to SAC-activated tonsillary B cells in the presence of excess cold HMWBCGF; lane 4: ${ }^{125} \mathrm{I}-\mathrm{HMW}-\mathrm{BCGF}$; lane $5:{ }^{125} \mathrm{I}-\mathrm{HMW}$-BCGF crosslinked to its $R$ on leukemic B cells from CLL 6 in the presence of excess cold HMW-BCGF; lane 6: ${ }^{125}$ I-HMW-BCGF crosslinked to its $R$ on leukemic B cells from CLL 6; lane 7: ${ }^{125}$ I-HMW-BCGF crosslinked to its $R$ on leukemic cells from CLL 7 in the presence of excess cold HMW-BCGF; lane 8: ${ }^{125} \mathrm{I}-\mathrm{HMW}-\mathrm{BCGF}$ crosslinked to its $\mathrm{R}$ on leukemic cells from CLL 7 .

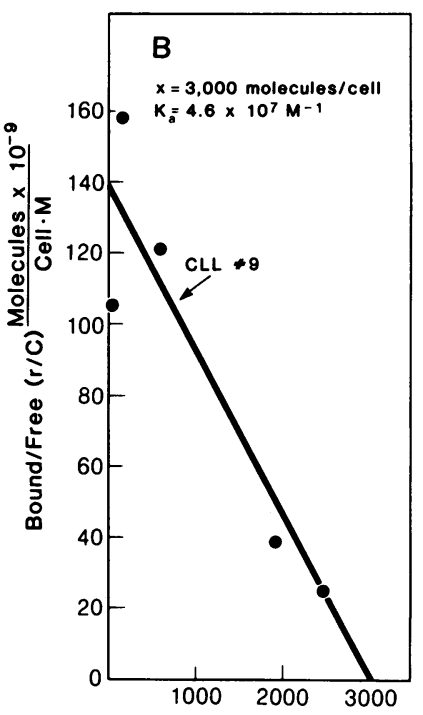

Figure 5. Specific equilibrium binding data of ${ }^{125} \mathrm{I}-\mathrm{BA}-5$ to CLL cells at $4^{\circ} \mathrm{C}$. $(A)$ Binding isotherm. The indicated amounts of ${ }^{125} \mathrm{I}-\mathrm{BA}-5(1.5 \times$ $\left.10^{17} \mathrm{cpm} / \mathrm{mol}\right)$ were incubated with CLL cells $\left(10 \times 10^{6}\right.$ cells in duplicate) for $24 \mathrm{~h}$ at $4^{\circ} \mathrm{C}$ with and without 100 fold molar excess unlabeled BA-5 $\mathrm{MAb}$, and the specific binding was determined as detailed in the Methods section. Each point represents the mean of duplicate determinations. (B) Scatchard plot. The specific equilibrium binding data on HMW-BCGF responsive CLL 9 yielded a straight linear regression line when transformed and replotted in the Scatchard coordinate system. but with very few exceptions failed to stimulate CLL cells in the absence of co-stimulants or mitogens include IL-1, IL-2, IL-4, IL-5, gamma interferon (IFN), $20 \mathrm{kD}$ BCGF, $50 \mathrm{kD}$ BCGF, and B cell stimulatory factor 2 (BSF-2) (24-32). Karray et al. (27), Hivroz et al. (28), and Ghaderi et al. (31) observed a marked heterogeneity and inconsistency in responsiveness of CLL cells to IL-1, IL-2, IL-4, IL-5, $20 \mathrm{kD}$ BCGF, $50 \mathrm{kD}$ $\mathrm{BCGF}$, and gamma IFN providing suggestive evidence that none of these GF by itself is likely to play a key role in leukemogenesis of B lineage CLL and expansion of clonogenic CLL cell populations. The present study provides direct and unprecedented evidence that $60 \mathrm{kD}$ HMW-BCGF stimulates CLL colony formation in the absence of costimulants and its activity does not depend on accessory cell populations since virtually pure populations of FACS sorted CLL cells also show a strong proliferative response to HMW-BCGF. Taken together, these findings prompt the hypothesis that HMWBCGF may be an important hematopoietic GF regulating the proliferative activity of clonogenic "mature" leukemic B cells in CLL. By contrast, LMW-BCGF appears to be a major growth stimulatory molecule for clonogenic "immature" leukemic B cell precursors from B-lineage acute lymphoblastic leukemia patients. The underlying reason for this difference is unknown but may be related to a differentiation linked modulation of BCGF $R$ expression. These observations also provide corraborative evidence that different target cell populations for clonal expansion are involved in immature $B$ cell malignancies (such as BCP-ALL) versus mature B cell malignancies (such as CLL).

HMW-BCGF does not stimulate resting normal B cells (7, 8) or normal BCPs in fetal hematopoietic organs (10). However, HMW-BCGF does stimulate leukemic immature BCPs from BCP ALL patients (12) and we now show that it also stimulates leukemic mature B cells from CLL, PLL, and HCL patients. Unlike resting normal B cells which bound only $\mathbf{0 . 6}$ fmol of HMW-BCGF $/ 10^{6}$ cells (=380 HMW-BCGF molecules/cell) in ligand binding assays and showed no proliferative response to HMW-BCGF, leukemic cells from CLL, HCL, and PLL patients proliferated in response to HMW-BCGF. HMW-BCGF responsive CLL cells bound 1.8-7.4 $\mathrm{fmol} / 10^{6}$ 
cells (1,080-4,440 molecules/cell) and HMW-BCGF responsive $\mathrm{HCl}$ cells bound $4.2-45.2 \mathrm{fmol} / 10^{6}$ cells $(=2,526-45,227$ molecules/cell) of ${ }^{125}$ I-HMW-BCGF. There were $\sim 3,000$ HMW-BCGF $R$ on HMW-BCGF responsive CLL cells, as determined by Scatchard analyses using ${ }^{125} \mathrm{I}-\mathrm{BA}-5 \mathrm{MAb}$, whereas normal resting $B$ cells express only 50-350 HMWBCGF binding sites reactive with BA-5 MAb (17). These differences may be a consequence of altered/amplified HMWBCGF R gene expression in leukemic B cells and BCPs.

Clonogenic cells have been implicated in maintanence and expansion of leukemic cell populations in B lineage leukemias. The current paucity of knowledge regarding clonogenic leukemic cells in acute or chronic leukemias of B lineage origin largely reflects the historic difficulties in culturing fresh leukemic cells in vitro. Considerable effort has been invested in developing cell culture techniques to reveal information about the immunobiologic features of clonogenic leukemic cells. Recently, we developed a colony assay system that enabled us to culture clonogenic leukemic cells from BCP ALL patients $(10-15)$. We have used this assay system to study the growth factor requirements and surface differentiation antigen profiles of normal and leukemic BCPs (10-15). Our comparative analyses of the immunobiologic features of leukemic BCPs and their putative normal counterparts in normal fetal bone marrow/liver revealed significant differences between normal and leukemic BCPs (10), emphasizing the potential value of this colony assay system for a better understanding of the basic biology of human $B$ lineage lymphoid malignancies. The present study demonstrates that, when HMW-BCGF is used for stimulation, this assay system allows reproducible proliferation and colony formation of fresh leukemic B cells from CLL patients, as well. Experimental data produced in this model system will likely provide valuable information about the immunobiologic features of leukemic CLL B cells and their putative normal counterparts in human lymphoid tissues. The availability of a reproducible CLL colony assay should promote future analyses of GF interactions at the level of clonogenic CLL cells. A major finding of potential clinical significance presented in this paper is that BA-5 (anti-HMW-BCGF R) MAb inhibited HMW-BCGF induced CLL cell proliferation. The opportunity is thus provided for using BA-5 MAb to disrupt HMW-BCGF/HMW-BCGF $R$ interactions in malignant $B$ lymphocyte populations which may ultimately lead to a more effective treatment strategy for high risk CLL.

\section{Acknowledgments}

We thank K. Waddick, P. MacFarland, V. Kuebelbeck, H. Mostowski, and L. Chesky for technical assistance during the immunobiological assays, BCGF purification, and affinity crosslinking experiments; Mike Hupke for technical assistance during FACS analyses and cell sorting, J. Kersey and K. Gajl-Peczalska (University of Minnesota) for access to leukemic bone marrow specimens, and B. Doerken (Medizinische Poliklinik, University of Heidelberg Medical School, Federal Republic of Germany) for providing HCL cells.

This work was supported in part by R29 CA 42111, R01 CA 42633, and P01 CA 21737 awarded by the National Cancer Institute, and Special Research Grants awarded by the Minnesota Medical Foundation, Children's Cancer Research Fund (CCRF), and Bone Marrow Transplantation Research Fund, University of Minnesota. F. M. Uckun is a Scholar of the Leukemia Society of America. This is publication \#16 from the Tumor Immunology Laboratory, University of Minnesota.

\section{References}

1. Greaves, M. F. 1986. Differentiation-linked leukemogenesis in lymphocytes. Science (Wash. DC). 234:697-704.

2. Howard, M., K. Nakanishi, and W. E. Paul. 1984. B-cell growth and differentiation factors. Immunol. Rev. 78:185.

3. O'Garra, A., S. Umland, T. DeFrance, and J. Christiansen. 1988. B-cell factors are pleiotropic. Immunol. Today. 9:45-53.

4. Groopman, J. E. 1987. Hematopoietic growth factors: From methylcellulose to man. Cell. 50:5-6.

5. Clark, S. C., and R. Kamen. 1987. The human hematopoietic colony-stimulating factors. Science 236:1229-1237.

6. Mehta, S. R., D. Conrad, R. Sandler, J. Morgan, R. Montagna, and A. L. Maizel. 1985. Purification of human B-cell growth factor. $J$. Immunol. 135:3298-3302.

7. Ambrus, J. L., and A. S. Fauci. 1985. Human B lymphoma cell line producing B-cell growth factor. J. Clin. Invest. 75:732-739.

8. Ambrus, J. L., C. H. Jurgensen, E. J. Brown, and A. S. Fauci. 1985. Purification to homogeneity of a high molecular weight human B-cell growth factor, demonstration of specific binding to activated B-cells and development of a monoclonal antibody to the factor. $J$. Exp. Med. 162:1319-1335.

9. Kishimoto, T., K. Yoshizaki, M. Okada, T. Kuritani, H. Kikutani, N. Sakaguchi, Y. Miki, H. Kishi, T. Nakagawa, K. Shimuzu, K. Fukunaga, and T. Taga. 1985. Growth and differentiation factors and activation of human B-cells. In Lymphokines. M. H. Schreier and K. A. Smith, editors. 10:15.

10. Uckun, F. M., and J. A. Ledbetter. 1988. Immunobiologic differences between normal and leukemic human B-cell precursors. Proc. Natl. Acad. Sci. USA. 85:8603-8607.

11. Ledbetter, J. A., P. S. Rabinovitch, C. H. June, C. W. Song, E. A. Clark, and F. M. Uckun. 1988. Antigen independent regulation of cytoplasmic calcium in B-cells with 12 kilodalton B-cell growth factor and anti-CD 19. Proc. Natl. Acad. Sci. USA 85:1897-1901.

12. Uckun, F. M., A. S. Fauci, A. S., N. A. Heerema, C. W. Song, S. R. Mehta, K. J. Gajl-Peczalska, M. Chandan, and J. L. Ambrus. 1987. B-cell growth factor receptor expression and B-cell growth factor response of leukemic B-cell precursors and B-lineage lymphoid progenitor cells. Blood. 70:1020-1034.

13. Uckun, F. M., W. Jaszcz, J. L. Ambrus, A. S. Fauci, K. J. Gajl-Peczalska, C. W. Song, M. R. Wick, D. E. Myers, K. Waddick, and J. A. Ledbetter. 1988. Detailed studies on expression and function of CD19 surface determinant using B43 monoclonal antibody. Blood. 71:13-29.

14. Uckun, F. M., K. J. Gajl-Peczalska, J. H. Kersey, L. L. Houston, and D. A. Vallera. 1986. Use of a novel colony assay to evaluate the cytotoxicity of an immunotoxin containing pokeweed antiviral protein against blast progenitor cells freshly obtained from patients with common B-lineage acute lymphoblastic leukemia. J. Exp. Med. 163:347-368.

15. Uckun, F. M., J. H. Kersey, K. J. Gajl-Peczalska, N. A. Heerema, A. J. Provisor, D. Haag, G. Gilchrist, C. W. Song, D. C. Arthur, J. Roloff, B. Lampkin, M. Greenwood, G. Dewald, and D. A. Vallera. 1987. Heterogeneity of cultured leukemic lymphoid progenitor cells from B-cell precursor ALL patients. J. Clin. Invest. 80:639-646.

16. Uckun, F. M., D. E. Myers, J. A. Ledbetter, S. E. Swaim, K. J. Gajl-Peczalska, and D. A. Vallera. 1988. Use of colony assays and highly potent anti-T-cell immunotoxins to elucidate the immunobiologic features of leukemic lymphoid progenitor cells in T-lineage acute lymphoblastic leukemia. J. Immunol. 140:2103-2111.

17. Ambrus, J. L., C. H. Jurgensen, E. J. Brown, P. MacFarland, and A. S. Fauci. 1988. Identification of a receptor for high molecular weight human B-cell growth factor. J. Immunol. 141:660-665.

18. Lee, W. T., and D. H. Conrad. 1985. J. Immunol. 134:518-525.

19. Gale, R. P., and K. A. Foon. 1985. Chronic lymphocytic leukemia: Recent advances in biology and treatment. Ann. Intern. Med. 103:101-120.

20. Bofill, M., G. Janossy, M. Janossa, G. D. Burford, G. J. Sey- 
mour, and E. Kelemen. 1985. Human B-cell development. II. Subpopulations in the human fetus. J. Immunol. 134:1531-1540.

21. Caligaris-Cappio, F., M. Gobbi, M. Bofill, and G. Janossy. 1982. Infrequent normal B-lymphocytes express features of B-chronic lymphocytic leukemia. J. Exp. Med. 155:623-628.

22. Andreeff, M., Z. Darzynkiewicz, T. K. Sharpless, B. D. Clarkson, and M. R. Melamed. 1980. Discrimination of human leukemia subtypes by flow cytometric analysis of cellular DNA and RNA. Blood. 55:282-287.

23. Fu, S. M., N. Chiorazzi, and H. G. Kunkel. 1979. Immunol. Rev. 48:23-44.

24. Cappio-Caligaris, F., M. Schena, L. Bergui, L. Tesio, M. Riva, G. Rege-Cambrin, A. Funaro, and F. Malavasi. 1987. C3b receptors mediate the growth factor induced proliferation of malignant Bchronic lymphocytic leukemia lymphocytes. Leukemia. 1:746-752.

25. Kawamura, N., A. Muraguchi, A. Hori, Y. Horii, S. Matsuura, R. R. Hardy, H. Kikutani, and T. Kishimoto. 1986. A case of human B cell leukemia which implicates an autocrine mechanism in the abnormal growth of Leu1 B cells. J. Clin. Invest. 78:1331-1338.

26. Perri, R. T., and N. E. Kay. 1982. Monoclonal CLL B cells may be induced to grow in an in vitro B cell colony assay system. Blood. 59:247-249.

27. Karray, S., H. Merle-Beral, A. Vazquez, J. Gerard, P. Debre, and P. Galanaud. 1987. Functional heterogeneity of B-CLL lymphocytes in dissociated responsiveness to growth factors and distinct requirements for a first activation signal. Blood. 70:1105-1110.
28. Hivroz, C., C. Grillot-Courvalin, J. Brouet, and M. Seligmann. 1986. Heterogeneity of responsiveness of chronic lymphocytic leukemic B cells to B-cell growth factors or interleukin 2. Eur. J. Immunol. 16:1001-1004.

29. Benjamin, D., L. S. Bazar, B. Wallace, and R. J. Jacobson. 1986. Heterogeneity of B-cell growth factor receptor reactivity in healthy donors and in patients with chronic lymphocytic leukemia. Relationship to B cell derived lymphokines. Cell. Immunol. 103:394 408.

30. Perri, R. T. 1986. Impaired expression of cell surface receptors for B-cell growth factor by CLL B-cells. Blood. 67:943-948.

31. Ghaderi, A. A., P. Richardson, C. Cardona, M. J. Millsum, N. Ling, S. Gillis, J. Ledbetter, and J. Gordon. 1988. Stimulation of B chronic lymphocytic leukemic populations by recombinant interleukin 4 and other defined growth promoting agents. Leukemia. 2:165170.

32. Ostlund, F., S. Einhorn, K. H. Robert, G. Juliusson, and P. Biberfeld. 1986. Chronic lymphocytic leukemia cells proliferate and differentiate following exposure to interferon in vitro. Blood. 67:152159.

33. Uckun, F. M., D. E. Myers, A. S. Fauci, and J. L. Ambrus. 1989. Leukemic B-cell precursors constitutively express functional receptors for human interleukin 1. Blood. 74:761-776.

34. Uckun, F. M., T. Gesner, D. E. Myers, C. W. Song, and A. Mufson. 1989. Leukemic B-cell precursors express functional receptors for human interleukin 3. Blood. 73:533-542. 